\title{
ipen
}

INSTITUTO DE PESQUISAS ENERGÉTICAS E NUCLEARES

Autarquia associada à Universidade de São Paulo

\section{APLICAÇÃO DO MÉTODO MICROBIOLÓGICO DEFT/APC E DO TESTE DO COMETA NA DETECÇÃO DO TRATAMENTO COM RADIAÇÃO IONIZANTE DE HORTALIÇAS MINIMAMENTE PROCESSADAS}

MICHEL MOZEIKA ARAÚJO

Dissertação apresentada como parte dos requisitos para obtenção do grau de mestre em ciências na área de tecnologia nuclear aplicações.

Orientador:

Dra. Anna Lucia C. H. Villavicencio

SÃO PAULO 


\section{INSTITUTO DE PESQUISAS ENERGÉTICAS E NUCLEARES}

Autarquia Associada à Universidade de São Paulo

\section{APLICAÇÃO DO MÉTODO MICROBIOLÓGICO DEFT/APC E DO TESTE DO COMETA NA DETECÇÃO DO TRATAMENTO COM RADIAÇÃO IONIZANTE DE HORTALIÇAS MINIMAMENTE PROCESSADAS}

\section{MICHEL MOZEIKA ARAÚJO}

Dissertação apresentada como parte dos requisitos para obtenção do Grau de Mestre em Ciências na Área de Tecnologia Nuclear Aplicações.

Orientador:

Dra. Anna Lucia C. H. Villavicencio

SÃO PAULO 
Aos meus pais, João e Vera, e à minha irmã Tamara, simplesmente, por tudo. 


\section{AGRADECIMENTOS}

À Dra. Anna Lucia C. H. Villavicencio pela confiança e orientação que começou cedo, ainda na iniciação científica, me preparando para a conclusão deste projeto;

Ao IPEN, especialmente ao Centro de Tecnologia das Radiações, representado pelo Dr. Wilson Aparecido Parejo Calvo, gerente do CTR, e pela Dra. Margarida Hamada, chefe de divisão de pesquisa e desenvolvimento do CTR, pelo constante apoio e prédisposição em ajudar e buscar soluções;

Ao Dr. Leonardo Gondim de Andrade e Silva, por compartilhar experiências e aprendizado durante a monitoria PAE;

À Dra. Evelise Oliveira Telles e à Dra. Simone de Carvalho Balian da Faculdade de Veterinária e Zootecnia da USP, pela valiosa colaboração e ensinamentos, assim como por disponibilizar seu laboratório e equipamentos, imprescindíveis para a materialização desta pesquisa;

Ao Dr. Eric Marchioni pela valiosa ajuda no planejamento e no desenvolvimento deste trabalho;

À Sandra, auxiliar de laboratório, e ao Bispo, técnico de laboratório, ambos do Laboratório de Higiene Alimentar (FMVZ/USP) pela importante ajuda nas análises microbiológicas;

À Dra. Olga Zazuco Higa e à Dra. Andrea Cecilia Dorión Rodas, do Centro de Biotecnologia (IPEN), por terem disponibilizado seu laboratório e equipamento, essenciais para a realização deste trabalho;

À Dra. Sueli Borrely, por ceder equipamentos essenciais para o desenvolvimento da parte laboratorial;

À MSc. Yasco Kodama e ao Paulo de Souza Santos por ajudarem no tratamento por radiação das amostras no irradiador multi-propósito;

Aos engenheiros Elizabeth Somessari e Carlos Gaia da Silveira, pelo constante auxílio no processamento por irradiação das amostras no Gammacell;

Ao Marcos e à Claudia pelo imprescindível auxílio nos assuntos administrativos;

Aos colegas do laboratório e agora grandes amigos, com os quais dividi grande parte do meu tempo e que inúmeras vezes me ajudaram na realização deste trabalho: Simone, Ingrid, Patrícia, Camilo, Priscila, Renato, Gustavo, Débora, Fernanda, Thaíse, Renata, Vladimir e Reginaldo; 
À Vera, a mais recente aluna de iniciação científica do nosso laboratório, pela ajuda sempre presente e indispensável para o desenvolvimento deste trabalho;

A todos os outros amigos que conquistei no IPEN, importantes tanto nos momentos sérios como nos de descontração durante este período: Rodrigo, Fábio, Marcela, Neto, Marco Antônio, Natália, Alessandro, Gabriel, Renata, Paula e Juliana;

Aos demais profissionais do Centro de Tecnologia das Radiações, pósgraduandos e alunos de iniciação científica pelo convívio harmonioso e enriquecedor;

Aos meus pais, João e Vera, e à minha irmã, Tamara, pelo constante apoio, paciência, estímulo e acima de tudo, pelo amor incondicional;

Ao CNPq, pelo auxílio financeiro, sem o qual o desenvolvimento deste projeto seria dificultado. 
“Caminante no hay camino, se hace camino al andar..."

Antonio Machado 


\title{
APLICAÇÃO DO MÉTODO MICROBIOLÓGICO DEFT/APC E DO TESTE DO COMETA NA DETECÇÃO DO TRATAMENTO COM RADIAÇÃO IONIZANTE DE HORTALIÇAS MINIMAMENTE PROCESSADAS
}

\section{MICHEL MOZEIKA ARAÚJO}

\begin{abstract}
RESUMO
O comércio de vegetais minimamente processados (VMP) tem crescido substancialmente nos últimos anos devido a sua conveniência, frescor e aparente salubridade. No entanto, o processamento mínimo não reduz as populações de microrganismos patogênicos para níveis seguros. A irradiação de alimentos é utilizada para estender a vida de prateleira e inativar patógenos presentes nos alimentos. Seu uso combinado com o processamento mínimo poderia aumentar a segurança e qualidade dos VMP. Dois diferentes métodos de detecção de alimentos irradiados, um biológico, o DEFT/APC, e outro bioquímico, o teste do cometa, foram aplicados a VMP com o objetivo de testar sua aplicabilidade na detecção do tratamento por radiação. O DEFT/APC é um método de varredura microbiológico baseado no uso da técnica de epifluorescência direta em filtro (DEFT) e da contagem padrão em placas (APC). O teste do cometa detecta o dano no DNA devido, por exemplo, a radiação ionizante. Amostras de acelga, agrião, alface, catalônia, couve, escarola, espinafre e repolho do comércio varejista foram irradiadas com $0,5 \mathrm{kGy}$ e $1,0 \mathrm{kGy}$ utilizando um irradiador de ${ }^{60} \mathrm{Co}$. O processamento por irradiação garantiu a redução de pelo menos dois ciclos logarítmicos nas populações de microrganismos aeróbios e psicrotróficos. Em geral, com o aumento das doses de radiação, as contagens DEFT se mantiveram similares independentemente do processamento por irradiação, enquanto as contagens APC diminuíram gradualmente. A diferença das duas contagens aumentou gradualmente com o incremento da dose em todas as amostras. Uma diferença entre o valor de DEFT e do APC maior a 2,0 log seria indicativa de que o VMP foi tratado por irradiação. O teste do cometa permitiu distinguir amostras não irradiadas das irradiadas, que mostraram diferentes tipos de cometas decorrentes da fragmentação do DNA. Tanto o método DEFT/APC quanto o teste do cometa foram satisfatoriamente utilizados como métodos de varredura para a detecção do tratamento por irradiação.
\end{abstract}




\title{
APLICATION OF THE MICROBIOLOGICAL METHOD DEFT/APC AND DNA COMET ASSAY TO DETECT IONIZING RADIATION PROCESSING OF MINIMALLY PROCESSED VEGETABLES
}

\section{MICHEL MOZEIKA ARAÚJO}

\begin{abstract}
Marketing of minimally processed vegetables (MPV) are gaining impetus due to its convenience, freshness and apparent healthy. However, minimal processing does not reduce pathogenic microorganisms to safe levels. Food irradiation is used to extend the shelf life and inactivation of food-borne pathogens. Its combination with minimal processing could improve the safety and quality of MPV. Two different food irradiation detection methods, a biological, the DEFT/APC, and another biochemical, the DNA Comet Assay were applied to MPV in order to test its applicability to detect irradiation treatment. DEFT/APC is a microbiological screening method based on the use of the direct epifluorescent filter technique (DEFT) and the aerobic plate count (APC). DNA Comet Assay detects DNA damage due to ionizing radiation. Samples of lettuce, chard, watercress, dandelion, kale, chicory, spinach, cabbage from retail market were irradiated $0.5 \mathrm{kGy}$ and $1.0 \mathrm{kGy}$ using a ${ }^{60} \mathrm{Co}$ facility. Irradiation treatment guaranteed at least $2 \mathrm{log}$ cycle reduction for aerobic and psychrotroph microorganisms. In general, with increasing radiation doses, DEFT counts remained similar independent of irradiation processing while APC counts decreased gradually. The difference of the two counts gradually increased with dose increment in all samples. It could be suggested that a DEFT/APC difference over $2.0 \log$ would be a criteria to judge if a MPV was treated by irradiation. DNA Comet Assay allowed distinguishing non-irradiated samples from irradiated ones, which showed different types of comets owing to DNA fragmentation. Both DEFT/APC method and DNA Comet Assay would be satisfactorily used as a screening method for indicating irradiation processing.
\end{abstract}




\section{SUMÁRIO}

Página

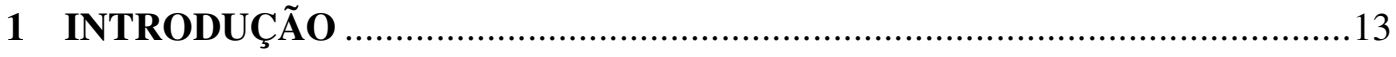

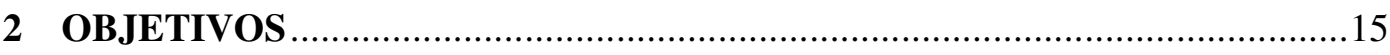

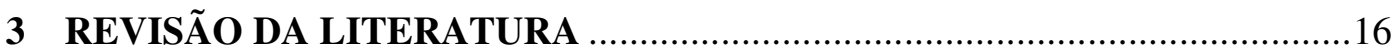

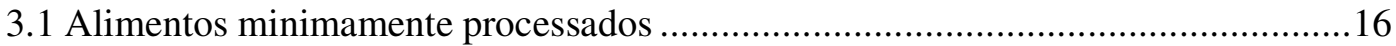

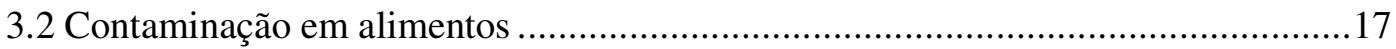

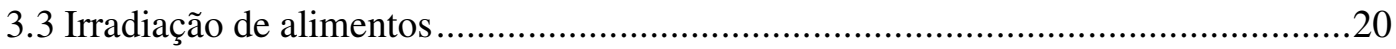

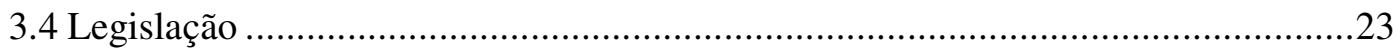

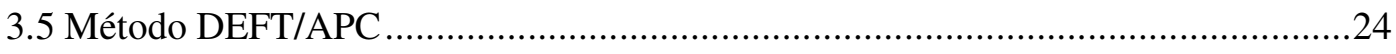

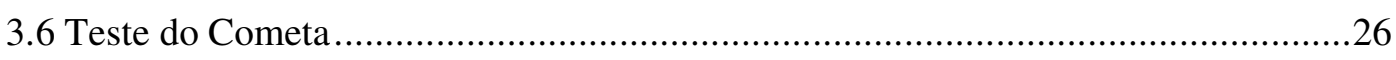

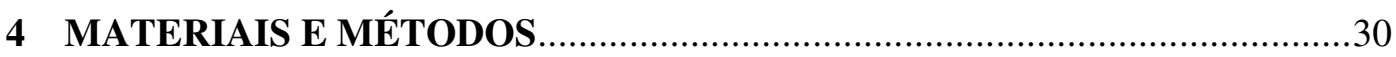

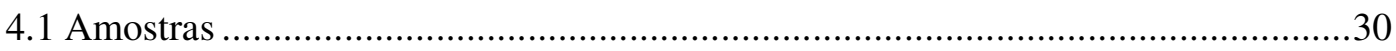

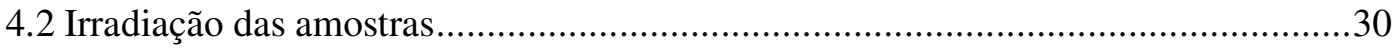

4.3 Avaliação microbiológica de hortaliças MP disponíveis no comércio......................30

4.3.1 Preparação da diluição decimal seriada ............................................................... 31

4.3.2 Contagem de microrganismos aeróbios mesófilos ..............................................31

4.3.3 Contagem de microrganismos psicrotróficos ..................................................... 31

4.3.4 Determinação do Número Mais Provável de coliformes totais e fecais ...............31

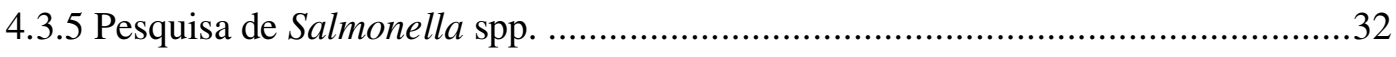

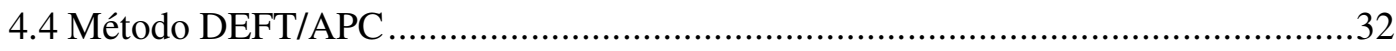

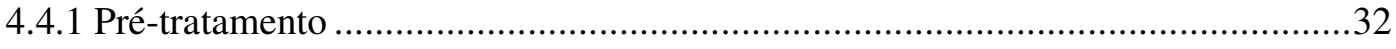

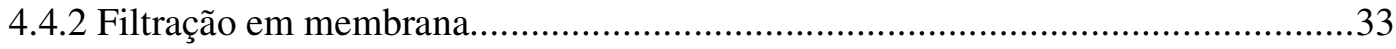

4.4.3 Coloração e enxágüe da membrana de filtro DEFT ........................................33

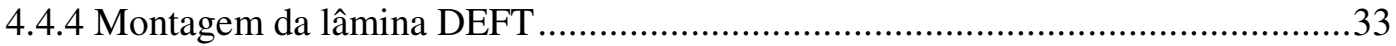

4.4.5 Semeadura em profundidade para determinação do APC …................................33

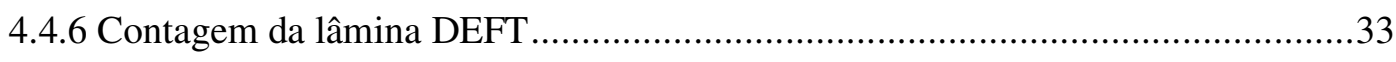

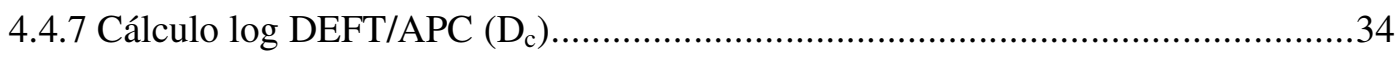

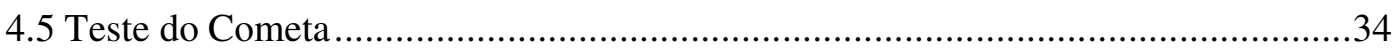

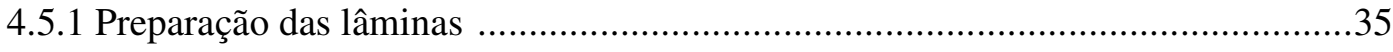




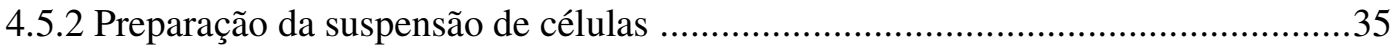

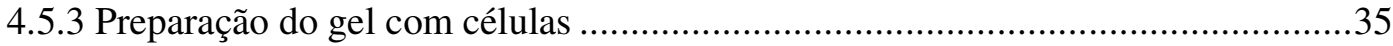

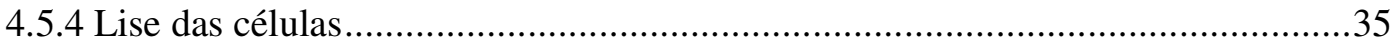

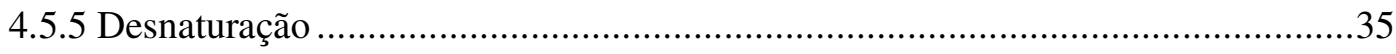

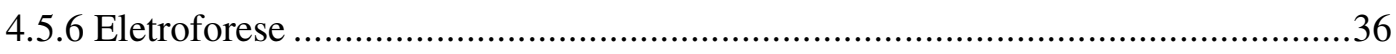

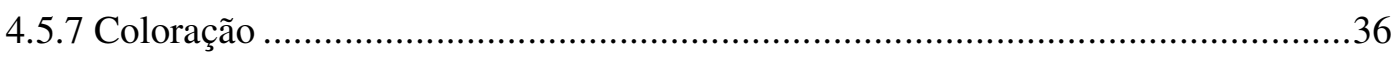

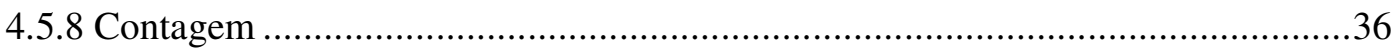

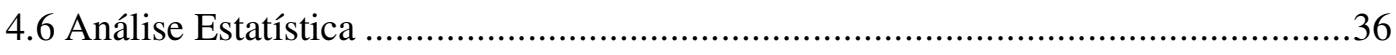

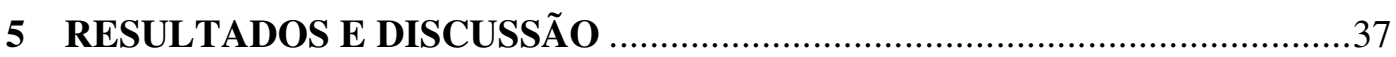

5.1 Avaliação microbiológica de hortaliças MP disponíveis no comércio.....................37

5.2 Detecção do processamento por irradiação pelo método DEFT/APC ....................42

5.3 Detecção do processamento por irradiação pelo teste do Cometa ...........................51

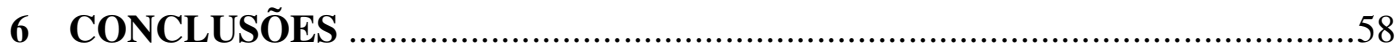

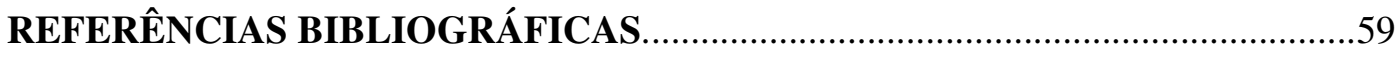




\section{LISTA DE TABELAS}

\section{Página}

TABELA 1 - Resultados da análise microbiológica obtidas de hortaliças MP adquiridas no comércio varejista da cidade de São Paulo, antes e depois do tratamento por radiação .... 38 TABELA 2 - Contagem DEFT, contagem APC e Dc de hortaliças MP adquiridas no comércio da cidade de São Paulo após o processo de irradiação...................................... 42 TABELA 3 - Frequiência de tipos de cometas nas amostras de hortaliças minimamente processadas estudadas após o processo de irradiação. .................................................... 52 


\section{LISTA DE FIGURAS}

\section{Página}

FIGURA 1 - Fotomicrografias de diferentes tipos de cometas após o processo de irradiação (aumento de 400X) 36

FIGURA 2 - Contagens de microrganismos aeróbios mesófilos presentes em amostras de hortaliças MP adquiridas no comércio varejista da cidade de São Paulo tratadas por radiação

FIGURA 3 - Contagens de microrganismos psicrotróficos presentes em amostras de hortaliças MP adquiridas no comércio varejista da cidade de São Paulo tratadas por radiação

FIGURA 4 - Contagens de coliformes totais presentes em amostras de hortaliças MP adquiridas no comércio varejista da cidade de São Paulo tratadas por radiação 40

FIGURA 5 - Efeito da irradiação nas contagens DEFT e APC de acelga.......................... 43

FIGURA 6 - Efeito da irradiação nas contagens DEFT e APC de agrião.......................... 44

FIGURA 7 - Efeito da irradiação nas contagens DEFT e APC de alface. ......................... 45

FIGURA 8 - Efeito da irradiação nas contagens DEFT e APC de almeirão....................... 46

FIGURA 9 - Efeito da irradiação nas contagens DEFT e APC de catalônia. ..................... 46

FIGURA 10 - Efeito da irradiação nas contagens DEFT e APC de escarola...................... 47

FIGURA 11 - Efeito da irradiação nas contagens DEFT e APC de espinafre. ...................47

FIGURA 12 - Efeito da irradiação nas contagens DEFT e APC de repolho...................... 48

FIGURA 13 - Histograma do log (DEFT/APC) das hortaliças MP analisadas.................. 49

FIGURA 14 - Células bacterianas recuperadas de amostra de escarola irradiada ............. 49

FIGURA 15 - Diferentes tipos de cometas encontrados em amostras de repolho .............. 51

FIGURA 16 - Freqüência de tipos de cometas em amostras de acelga após o processo de irradiação. .54

FIGURA 17 - Freqüência de tipos de cometas em amostras de agrião após o processo de irradiação. 54

FIGURA 18 - Freqüência de tipos de cometas em amostras de alface após o processo de irradiação. 54

FIGURA 19 - Freqüência de tipos de cometas em amostras de almeirão após o processo de irradiação. 
FIGURA 20 - Frequiência de tipos de cometas em amostras de catalônia após o processo de

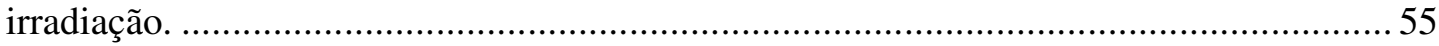

FIGURA 21 - Freqüência de tipos de cometas em amostras de couve após o processo de

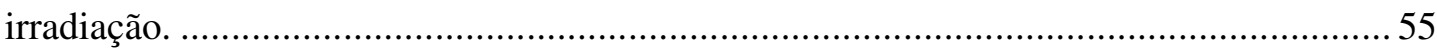
FIGURA 22 - Frequiência de tipos de cometas em amostras de escarola após o processo de

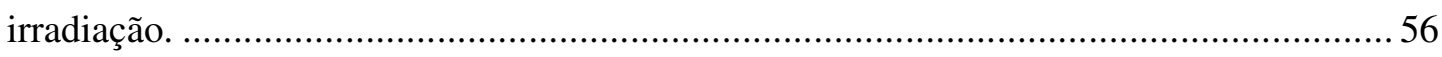
FIGURA 23 - Freqüência de tipos de cometas em amostras de espinafre após o processo de

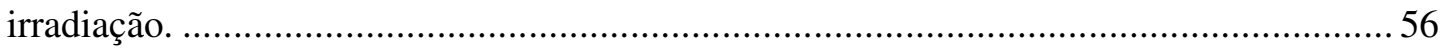
FIGURA 24 - Frequiência de tipos de cometas em amostras de repolho após o processo de

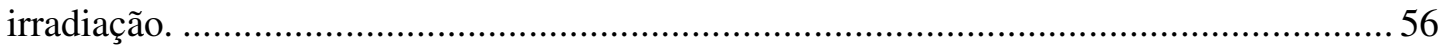




\section{INTRODUÇÃO}

Desde os primórdios da humanidade, o homem, demonstra preocupações com saúde e qualidade de vida, ou seja, preocupa-se com recursos básicos que garantam sua sobrevivência. Desta forma, dentro deste rol de recursos básicos encontram-se os alimentos (Farkas, 1998).

Durante séculos a humanidade procura formas de conservar melhor e por mais tempo os alimentos que consomem. A preservação e o armazenamento desses alimentos a baixa temperatura estão entre as técnicas de preservação mais antigas que se conhece. Além dessa, uma das formas mais recentes de preservação dos alimentos é o seu tratamento por radiação gama (Lee et al., 2006).

Atualmente, a qualidade é componente fundamental dos alimentos, como a segurança é um requisito indispensável da qualidade. A irradiação de alimentos é um processo físico de tratamento comparável à pasteurização térmica, ao congelamento ou enlatamento. Este processo envolve a exposição do alimento, embalado ou não, a um dos três tipos de energia ionizante utilizados: raios gama, raios $\mathrm{X}$ ou feixe de elétrons. Isto é feito em uma sala ou câmara especial de processamento por um tempo determinado (Diehl, 1995).

Em geral, o processo de irradiação nas doses recomendadas, acarreta poucas alterações químicas nos alimentos. Segundo Diehl (1992; 1995), nas doses de até 1kGy, as perdas nutricionais são consideradas insignificantes e nenhuma das alterações conhecidas encontradas nos alimentos irradiados é nociva ou perigosa, estando dentro dos limites encontrados normalmente para alimentos (Delincée et al., 1998).

Nas últimas décadas a irradiação de alimentos tem recebido atenção crescente devido às vantagens que apresenta sobre os métodos convencionais de processamento. Este método possibilita o tratamento dos alimentos após a embalagem, a conservação dos produtos em seu estado fresco, assim, alimentos perecíveis podem ser conservados por mais tempo sem perder sua qualidade e o produto praticamente não sofre alterações de temperatura (Farkas, 2006; Villavicencio, 1998). 
A radiação ionizante pode agir de modo direto ou indireto. A ação direta se deve a uma alteração química da macromolécula devido as ionizações ocorridas; já na ação indireta, as moléculas de água do meio celular são ionizadas (radiólise), originando os radicais livres que desencadeiam uma série de reações no interior da célula (Farkas, 1989; Murano et al., 1995).

Os efeitos de uma determinada dose de radiação sobre os organismos dependem de vários fatores tais como: tipo de organismo, número de organismos, composição do alimento, presença ou ausência de oxigênio, estado físico do alimento, idade do organismo, entre outros. (Jay, 2000).

Yersinia, Pseudomonas, Campylobacter, Aeromonas spp. e as células vegetativas de Bacillus cereus são as bactérias mais sensíveis à radiação ionizante com valores de $\mathrm{D}_{10}$ entre 0,04 e 0,20kGy em alimentos não congelados. Escherichia coli (incluindo a E. coli $\mathrm{O} 157: \mathrm{H7}$ ) e Arcobacter butzleri são também sensíveis à radiação com valores de $\mathrm{D}_{10}$ na faixa de 0,24 a $0,40 \mathrm{kGy}$ em produtos não congelados. Staphylococcus aureus, Salmonella spp. e Listeria monocytogenes são relativamente mais resistentes à radiação quando comparadas com outras bactérias patogênicas não formadoras de esporos, com valores de $\mathrm{D}_{10}$ entre 0,4 e $0,8 \mathrm{kGy}$ também em alimentos não congelados (Farkas, 1998).

Muitos métodos de detecção de alimentos irradiados têm sido utilizados e novas técnicas estão surgindo. As principais razões para o desenvolvimento destes métodos são: facilitar o comércio internacional, verificar a submissão dos produtos alimentícios às regulamentações existentes (por exemplo, obrigatoriedade de rotulagem), acentuar a confiança do consumidor na correta aplicação do processamento por irradiação e fundamentalmente proteger a liberdade de escolha dos consumidores (Delincée, 1993). 


\section{OBJETIVOS}

Verificar a qualidade microbiológica de amostras de hortaliças minimante processadas do comércio da cidade de São Paulo.

Avaliar a aplicabilidade do método microbiológico DEFT/APC para a detecção do tratamento com radiação gama de hortaliças minimamente processadas.

Avaliar a utilização do teste do Cometa na detecção do processamento por irradiação de hortaliças minimamente processadas. 


\section{REVISÃO DA LITERATURA}

\subsection{Alimentos minimamente processados}

O comércio de vegetais minimamente processados (MP) tem aumentado de forma significativa nos últimos anos. Estes produtos são submetidos a um processamento mínimo que tem por objetivo tornar o produto pronto para o consumo, mantendo ao máximo suas características de frescor, atendendo assim a demanda do consumidor por um produto mais conveniente, fresco e saudável (Alzamora et al., 2000). O aspecto saudável e fresco desses produtos pode, no entanto, ser apenas aparente quando a qualidade da matéria-prima, as condições do processo e as condições de conservação, seja de forma isolada ou combinada, permitam a contaminação, a sobrevivência e/ou a multiplicação de microrganismos, inclusive dos patogênicos (Alzamora et al., 2000; Nguyen-the et al., 1994).

Para os vegetais frescos em geral, a contaminação por microrganismos patogênicos pode ocorrer em diferentes fases, desde a sua produção até o consumo. Na fase de produção agrícola, a contaminação pode ter origem no solo contaminado, na água de irrigação contaminada, no adubo orgânico, nos excrementos de animais (domésticos ou silvestres), entre outros. Na colheita e no processamento, a contaminação pode ocorrer de forma cruzada com os operadores, contêineres, equipamentos e durante o transporte. Já na fase de comercialização, os microrganismos presentes no vegetal embalado podem multiplicar-se e, dependendo do tempo e da temperatura de conservação, podem atingir níveis que comprometem a qualidade do produto e/ou a saúde do consumidor (Beuchat, 1996; Nguyen-the et al., 1994).

Eles são empacotados, depois de lavados geralmente com solução clorada, em embalagens permeáveis e embarcados/estocados sob refrigeração até o consumo. A sanificação com solução clorada reduz a carga de microrganismos de 1 a 2 escalas logarítmicas, podendo chegar até 4 escalas logarítmicas. A baixa eficiência é devido a fatores como a rugosidade e dobras do vegetal que dificultam a ação mecânica da lavagem, a baixa penetração dos sanificantes e a rápida inativação do cloro pela matéria orgânica. Outro fator importante é a camada de cera produzida pelo próprio vegetal, que recobre os 
microrganismos presentes na sua superfície, reduzindo o efeito da ação mecânica da lavagem e impedindo a ação do sanificante (Alzamora et al., 2000; Thayer \& Rajkowski, 1999).

Como estes alimentos são frequentemente consumidos como componentes de saladas, um risco de saúde pública pode estar associado a eles. Uma vez que a sanitização por meios químicos, como por exemplo, o tratamento com hipoclorito, não é muito confiável, assim como um empacotamento sob atmosfera modificada, que embora inibam a flora aeróbia contaminante podem promover o crescimento de patógenos anaeróbicos, há a necessidade de um procedimento que possa reduzir a incidência de microrganismos patogênicos associados aos alimentos frescos, sem alterar a sua característica de minimamente processados. A radiação ionizante oferece um meio físico de pasteurização sem alterar o estado fresco destes produtos (Farkas et al., 1997; Martins et al., 2004).

\subsection{Contaminação em alimentos}

O consumo de vegetais frescos, frutas e sucos de frutas têm sido relacionados a surtos de doenças causadas por microrganismos. Estes incluem bactérias deteriorantes, tais como Pseudomonas spp. e Erwinia spp. Patógenos psicrotróficos como Listeria monocytogenes, Aeromonas hydrophila e Yersinia enterocolitica e mesófilos, como Salmonella, Escherichia coli O157:H7 e Clostridium botulinum são de interesse particular. Várias espécies de bactérias patogênicas para humanos e parasitas incluindo Escherichia coli O157:H7, L. monocytogenes, Salmonella spp, Shigella, Aeromonas hydrophila, Yersinia enterocolitica e Cyclospora cayetanensis foram encontradas em vegetais preparados; algumas proliferam sob condições de refrigeração foram responsáveis por estes surtos (Beuchat, 1996; Thayer et al., 1999; Goularte et al., 2004 ).

A maioria dos surtos alimentares causados por produtos frescos contaminados tem sido associada à presença de bactérias patogênicas, particularmente espécies de Enterobacteriaceae. Desses, Salmonella spp e Escherichia coli O157:H7 têm despertado maiores preocupações. Entre 1995 e 1998, nos Estados Unidos, ocorreram nove surtos de doenças transmitidas por alimentos, envolvendo mais de 1234 casos, causada pelo consumo de vegetais frescos contaminados com Salmonella spp ou E. coli O157:H7 (APHA, 2001). 
De acordo com a Resolução RDC nº12 de 02/01/01, da Agência Nacional de Vigilância Sanitária (ANVISA) do Ministério da Saúde, a legislação sanitária de alimentos exige para hortaliças "in natura" sanificadas ausência de Salmonella sp (em $25 \mathrm{~g}$ de amostra) e, no máximo, $10^{2}$ NMP (número mais provável) de coliformes fecais por grama de produto para preservação da saúde pública.

Salmonella é um dos microrganismos mais freqüentemente incriminados em surtos de enfermidades transmitidas por alimentos (ETAs) em diferentes países e envolvendo os mais variados tipos de produtos. As doenças causadas por Salmonella podem ser classificadas em três grupos: febre tifóide causada pela Salmonella Typhi, as febres entéricas causadas por Salmonella Paratyphi (A, B e C) e as salmoneloses causadas pelas demais salmonelas. A salmonelose é uma enterocolite que inclui diarréia, febre, dores abdominais e vômitos. A dose infectante depende do indivíduo, da espécie e do produto que veicula Salmonella. As menores doses necessárias para causar salmonelose estão relacionadas com produtos gordurosos onde 50 células foram suficientes para desencadear o processo (Franco \& Landgraf, 1996).

O reservatório natural de Salmonella é o trato intestinal do homem e de animais, onde as aves têm papel relevante. Está amplamente distribuída na natureza e é transmitida para o homem, principalmente, por meio de alimentos e água (Franco \& Landgraf, 1996; ICMSF, 1996).

E. coli $\mathrm{O} 157: \mathrm{H} 7$ causa no homem desde uma simples diarréia até síndromes mais complicadas como a colite hemorrágica, podendo evoluir para a síndrome da uremia hemolítica (HUS) ou síndrome trombótica trombocitopênica. A dose infecciosa ainda não está claramente definida e, segundo alguns pesquisadores são necessárias $50 \mathrm{UFC} / \mathrm{g}$ para iniciar a doença (Doyle et al., 2001; Johnson et al., 1995).

O reservatório natural de E. coli O157:H7 é o trato intestinal do gado. É transmitida para os humanos principalmente por meio de alimentos e água. A contaminação de vegetais minimamente processados pode ocorrer na plantação, na colheita e no transporte por contaminação direta com fezes de animais infectados, adubos orgânicos contaminados ou indiretamente por meio da água contaminada. No processamento, a contaminação ocorre de forma cruzada com equipamentos inadequadamente sanificados, 
água contaminada, operador e também quando o fluxo do processo é cruzado, ou seja, quando o produto limpo cruza com o produto sujo (Beuchat, 1996).

Sommers et al. (2006) observou que a dose de radiação gama suficiente para reduzir $90 \%\left(\mathrm{D}_{10}\right)$ da população de Salmonella spp., S. aureus, L. monocytogenes, E. coli O157:H7 e Y. enterocolitica em amostras de frango, frutas e vegetais inoculadas com as mesmas foi de 0,$61 ; 0,54 ; 0,47 ; 0,36$ e 0,15 , respectivamente.

Lee et al. (2006), em estudo sobre os efeitos da radiação gama sobre Salmonella Typhimurium, Escherichia coli, Staphylococcus aureus e Listeria ivanovii em amostras de pepino, espinafre e burdock minimamente processado, verificou que doses de radiação na faixa de 0,28 a $0,42 \mathrm{kGy}$, seriam suficientes para reduzir $90 \%$ destes microrganismos.

Goularte et al. (2004), trabalhando com amostras de alface minimamente processada irradiada, observou que os valores de $D_{10}$ de Salmonella variaram de 0,16 e $0,23 \mathrm{kGy}$ e para $E$. coli, foram encontrados valores na faixa de 0,11 a $0,12 \mathrm{kGy}$. No seu estudo, também verificou que um processamento com uma dose de até $0,9 \mathrm{kGy}$ reduziu a população de Salmonella spp. em $4 \log$ e de E. coli em 6,8 log, sem comprometer atributos sensoriais da hortaliça, como por exemplo odor, textura e cor.

Em geral, nos diversos estudos realizados, os valores de D10 variaram de 0,10 a 1,29kGy para Salmonella e de 0,12 a 0,42kGy para E. coli O157:H7 (Farkas, 1998; Rajkowski et al., 2000; Niemira et al., 2002).

Em razão da gravidade de alguns surtos envolvendo vegetais, das dificuldades para a eliminação destes microorganismos de vegetais crus e do grande crescimento do mercado de vegetais minimamente processados, alguns estudos têm recomendado a irradiação em combinação com o processo de higiene e sanificação para aumentar a segurança microbiológica e o tempo de vida útil. Nestes casos, as doses aplicadas devem ser baixas para não afetar as características sensoriais do produto (Farkas, 1989; Thayer et al., 1999). 


\subsection{Irradiação de alimentos}

A irradiação é o fenômeno físico pelo qual ocorre a emissão e propagação de energia através do espaço ou de uma matéria (Radomyski et al., 1994). A irradiação de alimentos é um meio de preservação dos alimentos que está em desenvolvimento desde o começo do século XX (Morehouse, 2002). O processamento de alimentos por radiação requer uma exposição controlada e cuidadosa frente à radiação ionizante de energia conhecida. A exposição deve ser adequada para produzir um resultado desejado, evitando, ao mesmo tempo, a degradação do alimento (WHO, 1994).

Os raios gama provenientes de ${ }^{60} \mathrm{Co}$ ou ${ }^{137} \mathrm{Cs}$, os raios $\mathrm{X}$ gerados por máquinas que operam com nível de energia de até $5 \mathrm{MeV}$ e os elétrons gerados por máquinas operadas com nível de energia de até $10 \mathrm{MeV}$, são os únicos tipos de radiação ionizante permitidos para utilização em alimentos pelo "Codex Alimentarius Commission" (CAC, 2003). A unidade utilizada denomina-se Gray (Gy), onde $1 \mathrm{~Gy}$ é equivalente à energia de 1 joule absorvido por $1 \mathrm{~kg}$ de material. A grande diferença entre os raios gama provenientes de uma fonte de ${ }^{60} \mathrm{Co}$ e os elétrons oriundos de um acelerador industrial, é o seu poder de penetração. A taxa de dose é a energia absorvida por unidade de tempo, assim, os irradiadores gama diferem dos aceleradores por possuírem uma baixa taxa de dose, levando mais tempo de irradiação enquanto que as irradiações nos aceleradores com sua alta taxa de dose podem ser muito mais rápidas (Diehl, 1995).

Os alimentos são tratados com radiação ionizante para alcançar diversos objetivos. Esta tecnologia de processamento dos alimentos pode aumentar a segurança dos alimentos pela redução dos níveis de bactérias patogênicas e outros microorganismos e parasitas causadores de doenças. A irradiação também inativa organismos daninhos dos alimentos, incluindo bactérias, mofos e leveduras. Pode ser eficaz na extensão da vida útil de frutas frescas e vegetais pela diminuição das mudanças biológicas normais associadas com os processos de crescimento e maturação, tais como brotamento e o amadurecimento. A radiação ionizante também se mostra promissora como um tratamento fitossanitário no controle de pestes, como parte de um programa de quarentena (Morehouse, 2002). Células vegetativas são, no geral, mais sensíveis à radiação ionizante do que os esporos bacterianos e estes, por sua vez são menos resistentes do que os bolores e leveduras (Diehl, 1995; Monk et al., 1995). 
A radiação ionizante quando é absorvida por um material biológico, pode ter ação direta ou indireta sobre o material que recebeu este processamento. O mecanismo primário no qual a radiação destrói os microrganismos é dado pela quebra das fitas duplas de DNA causando inativação dessa célula. Já o efeito indireto é ocasionado pela interação da radiação com a molécula de água e também outras moléculas presentes na matéria, o que acaba por gerar os chamados radicais livres. Estes irão interagir com outros constituintes do material biológico tratado com radiação, de maneira similar a que reagem nos alimentos. Esse efeito é importante em células vegetais, que possuem uma abundante quantidade de água (Aquino, 2003; Monk et al., 1995; Tritsch, 2000).

A irradiação deve ser aplicada em alimentos já embalados, porém não evita a re-contaminação ou a re-infestação. A qualidade do alimento irradiado, bem como o de outro alimento, é função da qualidade do produto original. A radiação ionizante penetra profundamente no alimento, reduzindo e/ou eliminando o número de microorganismos, sem elevar significativamente a temperatura do produto (FDA, 1999). Portanto, é conhecida como esterilização a frio. É a forma de radiação escolhida para os alimentos porque, quando empregada de maneira correta, produz o efeito desejado com respeito as características do produto, não induzindo radioatividade nos alimentos ou nas embalagens. Além disso, está amplamente disponível e seu custo permite o seu uso em escala comercial (Farkas, 2001, 2006).

Os alimentos em geral, contêm alguns componentes-chaves que, embora presentes em concentrações muito baixas, regulam o sabor, aspecto e valor nutritivo (WHO, 1994). Esses componentes são muito sensíveis à irradiação e, se a dose de radiação for alta, pode causar transformações prejudiciais no sabor, odor e cor desses alimentos (Villavicencio, 1998, Delincée, 1998b). Em geral, o processo de irradiação nas doses recomendadas, acarreta poucas alterações químicas nos alimentos. Segundo Diehl (1992; 1995), com doses de até 1,0kGy, as perdas nutricionais são consideradas insignificantes e nenhuma das alterações conhecidas encontradas nos alimentos irradiados é nociva ou perigosa, estando dentro dos limites encontrados normalmente para alimentos (Delincée et $a l .$, 1998). As perdas são menores quando o tratamento pela radiação é conjugado com baixa temperatura e vácuo, podendo-se assim, aumentar as doses de radiação, sem prejuízo do valor nutricional do alimento (Diehl et al., 1992). Pesquisas demonstraram que macronutrientes tais como proteínas, carboidratos e gorduras são relativamente estáveis a 
doses de até 10kGy, e que os micronutrientes, principalmente as vitaminas, podem ser sensíveis a qualquer método de tratamento de alimentos (Villavicencio et al., 2000).

Entre 1964 e 1997, a Organização Mundial de Saúde acompanhou os resultados desses estudos com alimentos irradiados, em conjunto com Organização das Nações Unidas para Agricultura e Alimentação (FAO) e a Agência Internacional de Energia Atômica (IAEA), com base em uma série de reuniões com especialistas de diversos países do mundo. Na reunião de setembro de 1997, a conclusão final divulgada foi: a OMS aprova e recomenda a irradiação de alimentos, em doses que não comprometam suas características organolépticas, sem a necessidade de testes toxicológicos. A partir disto, a irradiação de determinados alimentos e ingredientes para alimentos foi aprovada pelas autoridades de saúde em aproximadamente 60 países (Delincée, 1998). Os alimentos que foram tratados por irradiação devem estar corretamente embalados e etiquetados para indicar que, a este produto, foi aplicado este processo. Devem ser utilizados os termos "irradiado" ou "tratado por radiação ionizante" (CAC, 2003).

É fundamental para este processo que se utilizem boas práticas de fabricação (“Good Manufacturing Practices - GMP”), já que o processamento por irradiação não pode melhorar a má qualidade dos produtos alimentícios ou uma manipulação indevida, pois não reverte o processo fisiológico e químico da decomposição (Delincée, 1998).

Em função do aumento do comércio internacional de alimentos e das crescentes exigências regulatórias dos mercados consumidores, cada vez mais países importadores e exportadores têm demonstrando interesse na irradiação de alimentos e desenvolvido pesquisas na aplicação prática desta tecnologia e de métodos de detecção do tratamento (ICGFI, 1999).

Métodos de detecção do processamento por irradiação têm sido desenvolvidos e padronizados para uma grande gama de alimentos, incluindo especiarias, carnes, grãos, raízes e tubérculos, vegetais e outros (Farkas, 2006). 


\subsection{Legislação}

A salubridade (inocuidade toxicológica, adequação nutricional e segurança microbiológica) de alimentos irradiados tem sido cuidadosamente avaliada por uma ampla pesquisa sem precedentes e testada por mais de 50 anos. Atualmente, aproximadamente 50 países concedem autorizações nacionais para o tratamento por radiação de pelo menos um ou mais itens alimentícios ou classes de alimentos. Mais de 30 destes países estão atualmente aplicando o processamento de irradiação de tais mercadorias com propósitos (semi) comerciais (Farkas, 2006).

No Brasil, a legislação para alimentos irradiados, incluindo os decretos e resoluções são apresentados de forma resumida a seguir:

$\rightarrow$ Decreto-lei no. 986 de 21 de outubro de 1969.

Estabelece normas gerais sobre alimentos. Inícios da Legislação brasileira sobre irradiação de Alimentos.

$\rightarrow$ Decreto no 72.718 de 29 de Agosto de 1973.

Estabelece normas gerais para processamento. Estocagem, transporte, importação e exportação, venda e consumo de alimentos irradiados. Estabelece o logo da Radura no rótulo de produtos irradiados.

$\rightarrow$ Portaria DINAL nº 09 de 08 de março de 1985 (MS)

Aprova normas gerais para a irradiação de alimentos no Brasil, indicando para cada caso o tipo, nível e dose média de energia de radiação e o tratamento prévio conjunto ou posterior. Limitada a dose de $10 \mathrm{kGy}$ e proibida a re-irradiação. Ampliação da autorização a outros tipos de alimentos que não constavam na portaria anterior.

$\rightarrow$ Portaria DINAL no 30 de 25 de setembro de 1989

Amplia a autorização a outros tipos de alimentos que não constavam de portaria anterior. 
$\rightarrow$ Resolução ANVISA - RDC nº. 21 de 26 de janeiro de 2001.

Revoga as Portarias DINAL n .09 de 08 de Março de 1985 e nº 30 de 25 de setembro de 1989.

“4.3. Dose absorvida: Qualquer alimento poderá ser tratado por radiação desde que sejam observadas as seguintes condições:

A dose mínima absorvida deve ser suficiente para alcançar a finalidade pretendida; a dose máxima absorvida deve ser inferior àquela que comprometeria as propriedades funcionais e ou atributos sensoriais do alimento".

\subsection{Método DEFT/APC}

A técnica de epifluorescência direta em filtro (DEFT) é um método originalmente desenvolvido para a rápida enumeração de microrganismos em amostras de leite cru. A técnica se baseia na filtração em membrana da amostra que retém os microrganismos. Depois da filtração a membrana é corada com alaranjado de acridina, um corante fluorescente, logo é lavado e colocado sobre uma lâmina de microscopia. O corante se liga a ácidos nucléicos (DNA e RNA) dentro das células microbianas, deste modo qualquer microrganismo na membrana pode ser facilmente visualizado e contado com auxílio de um microscópio de epifluorescência. O procedimento total pode levar apenas 30 minutos (Pettipher et al., 1980).

As características das populações microbianas de alimentos irradiados têm sido utilizadas para o desenvolvimento de métodos de detecção de alimentos irradiados (Delincée, 1998). Um método microbiológico baseado no uso da técnica de epifluorescência direta em filtro (direct epifluorescent filter technique - DEFT) e a contagem de aeróbios em placa (aerobic plate count - APC) tem sido usado para detecção de especiarias irradiadas (Boisen et al., 1992; Wirtanen et al., 1993). Este método foi validado em um estudo colaborativo que envolveu oito laboratórios na detecção de especiarias irradiadas e também tem sido testado em uma grande variedade de alimentos tais como carne, leite, frutos do mar e frango (Belliardo, 1993). Até o presente momento, nenhum estudo foi direcionado na detecção de hortaliças minimamente processadas tratadas por radiação. 
A contagem DEFT enumera o número total de microrganismos contaminantes, independentemente da viabilidade dos mesmos. A contagem APC indica o número de microrganismos viáveis capazes de formar colônias sobre uma placa de ágar e é expressa em unidades formadoras de colônias (UFC). Para uma amostra não irradiada, as contagens obtidas por DEFT são muito similares àquelas resultantes da contagem APC porque aproximadamente todas as amostras presentes estão vivas. Quando o APC de uma amostra irradiada é comparado com a contagem DEFT da mesma amostra, o APC encontrado é consideravelmente inferior a contagem obtida por DEFT, assim, a diferença entre as contagens indica que a amostra pode ter sido irradiada (Jones et al., 1994). De igual maneira, em amostras irradiadas, a maioria dos microrganismos viáveis é morta e o resultado da subtração da contagem DEFT pela contagem APC aumenta (Boisen et al., 1992; Schreiber et al., 1993).

Alguns estudos sugerem que diferenças entre log DEFT e log APC maiores ou iguais a 4,0 seriam um indicativo de que a amostra foi descontaminada, por exemplo, pelo processamento por irradiação. Da mesma maneira, outros tratamentos como calor e branqueamento também podem levar a morte dos microrganismos, assim resultados positivos devem ser comprovados com um método confirmatório de detecção de alimentos irradiados, como por exemplo, termoluminescência de minerais de silicato (EN 1788) e espectroscopia ESR de celulose (EN 1787) (Boisen et al., 1993; Manninen et al., 1991; Torben et al., 2006); Delincée, 1996).

Hammerton et al. (1996), em seu estudo com especiarias irradiadas, demonstraram que para a maioria das especiarias analisadas uma diferença log $($ DEFT/APC) $>4,0$ seria um indicativo do tratamento com uma dose de radiação de $2,5 \mathrm{kGy}$.

Analisando pelo método DEFT/APC, sete diferentes especiarias irradiadas com doses de 5,0kGy e 10,0kGy através da contagem das lâminas DEFT visualmente e automaticamente, Wirtanen et al. (1993) verificaram que os valores médios para as diferenças entre a contagem DEFT e a contagem APC foram de 6,1; 5,1 e 1,4 log respectivamente para $10 \mathrm{kGy}, 5 \mathrm{kGy}$ e controle, independentemente da contagem visual ou automática. Desta forma concluíram que as amostras foram irradiadas com pelo menos 
5,0kGy se a diferença entre log DEFT e log APC é de pelo menos 3,5 unidades logarítmicas.

Jones et al. (1995), avaliando a aplicabilidade do método em amostras de carne resfriada e congelada irradiadas com doses de 0,5kGy; 5,0kGy e $10 \mathrm{kGy}$, obteve valores iguais ou superiores a 4 log para aquelas amostras irradiadas com doses acima de 5,0kGy.

Outro trabalho, avaliando o método DEFT/APC a amostras de frango congeladas irradiadas com doses de $0 ; 3,0 ; 5,0$ e 7,0kGy em acelerador de elétrons, encontraram valores médios da diferença entre log DEFT e $\log$ APC de 1,14; 3,16; 3,68 e 3,79 unidades logarítmicas, respectivamente. Neste estudo, propõem que uma diferença de pelo menos duas unidades logarítmicas podem ser consideradas o valor limite indicativo de um provável tratamento por radiação (Wirtanen et al., 1995).

A contagem DEFT também proporciona uma idéia da qualidade bacteriológica de alimentos crus, que não podem ser obtidas por métodos convencionais para a determinação de bactérias viáveis. Diferenças entre as contagens APC e DEFT podem ser induzidas por outros tratamentos nos alimentos acarretando a morte dos microorganismos, como por exemplo, o calor, assim os resultados positivos devem ser confirmados (Hammerton, 1996; Pettipher, 1983).

\subsection{Teste do Cometa}

O teste do cometa (DNA Comet Assay), também denominada eletroforese em microgel, foi introduzido por Östling e Johanson em 1984 como uma técnica eletroforética para a direta visualização do dano no DNA em células individuais (Östling \& Johanson, 1984). Quando as células são submetidas a um campo elétrico, os fragmentos de DNA migram para o anodo adquirindo a aparência de um cometa. A região nuclear dá origem à cabeça do cometa enquanto que os fragmentos dão origem às caudas cuja extensão está intimamente relacionada com a intensidade do dano (Fairbairn et al., 1995; McKelveyMartin et al., 1993). Östling \& Johanson (1984) observaram que a migração destes fragmentos era uma função da dose de radiação. 
Têm sido considerados dois princípios que determinam o padrão de formação do cometa. A habilidade de migração dos fragmentos de DNA é uma função tanto do tamanho do DNA quanto do número de fragmentos quebrados que iriam se unir a fragmentos maiores do DNA, os que podem migrar uma curta distância desde o núcleo. A extensão de migração dos fragmentos de DNA inicialmente aumenta com o dano, porém, atinge um máximo que é definido pelas condições da eletroforese, mas não pelo tamanho dos fragmentos. Virtualmente, todas as células eucarióticas podem ser processadas para analisar o dano no DNA usando o teste do cometa (Fairbairn et al., 1995; McKelveyMartin et al., 1993).

O teste do cometa tem sofrido várias modificações, porém, os seus princípios estão baseados na versão neutra ou alcalina. Em geral, sob condições alcalinas são medidas as quebras simples e duplas e os sítios álcali-lábeis, enquanto sob condições neutras somente são observadas as quebras duplas da fita do DNA (Cerda, 1993; Fairbairn et al., 1995; Klaude et al., 1996).

Esta técnica, hoje em dia, é amplamente aceita e está sendo utilizada em uma variedade de áreas de investigação como: estudos de genotoxicidade, estudos de reparo do DNA, biomonitoramento ambiental, estudo de células apoptóticas, monitoramento humano, entre outras (Rojas et al., 1999; Olive, 1999; Koppen et al., 1999; Fairbairn et al., 1995; Malyapa et al., 1998; Ross et al., 1995; Choucroun et al., 2001; Kassie et al., 2000).

O uso do teste do cometa na detecção de alimentos irradiados foi sugerido por Östling \& Hofsten (1988) e por Johanson (1991). Cerda et al. (1993) aplicou este método pela primeira vez em amostras de alimentos utilizando um protocolo neutro. Para simplificar o teste utilizou uma camada simples de agarose em vez de uma camada "sanduíche" e, pelo fato de as doses de radiação, usadas na irradiação de alimentos, causarem danos expressivos no DNA, utilizou um pH neutro em combinação com baixa voltagem e tempo curto de eletroforese.

O teste do cometa tem sido aplicado a um grande número de alimentos tanto de origem animal e vegetal. As vantagens deste teste, no entanto, para alimentos não expostos ao calor, são sua velocidade e simplicidade, visto que a corrida eletroforética demora apenas alguns minutos. O DNA pode ser visualizado mediante coloração com diversos 
corantes, como por exemplo, alaranjado de acridina, brometo de etídio, nitrato de prata e outros.

Diversos estudos avaliaram o efeito do tratamento por radiação na degradação do DNA de alimentos. Delincée (1998a) estudou o efeito da radiação ionizante de raios gama na fragmentação do DNA de toronjas e observou que as frutas irradiadas com $0,2 \mathrm{kGy}$ e doses maiores mostraram a típica fragmentação do DNA.

Marín-Huachaca et al. (2002), utilizando o teste do Cometa para a identificação de mamão, melão e melancia processada por radiação gama, verificaram que amostras irradiadas com doses de até 1,0kGy mostraram uma típica fragmentação do DNA, enquanto que as células das amostras não irradiadas apareceram intactas. Em um trabalho complementar realizado por Marín-Huachaca et al. (2004), analisando laranjas, limões, maças, melancias e tomates irradiados com doses de até 4,0kGy também foi corroborado o resultado anterior, incrementos nas doses de radiação acarretaram uma maior fragmentação do DNA e o surgimento de diversos tipos de cometas.

Em pesquisa utilizando o teste do cometa na detecção de feijões tratados por radiação, foi verificado que a densidade de DNA na cauda dos cometas aumentou acompanhando o incremento na dose de radiação. Amostras não irradiadas apresentaram uma pequena migração do DNA (Khan et al., 2002).

Segundo estudo de Barros et al. (2002), foi encontrada uma freqüência elevada de cometas com pouca fragmentação nas amostras controle de trigo e quantidades crescentes de outros tipos de cometa com o incremento das doses de radiação, quando utilizado o teste do cometa na identificação de trigo irradiado após um período de estocagem superior a 6 meses.

Conforme dados apresentados por Villavicencio et al. (2004, 2007), igualmente foi verificado que o dano ao DNA, baseado no incremento de sua distância de migração, aumentou com doses de radiação crescentes, quando estudados os efeitos da radiação ionizante em grãos de soja selvagens e transgênicos. Araújo et al. (2004) também corroborou que doses de radiação crescentes promoveram uma grande fragmentação do DNA em amostras de carne de frango, originando assim diversos tipos de cometas. 
O teste do cometa é considerado como um método de varredura (screening), adequado para detectar se o alimento foi processado por irradiação ou não e, seus resultados deverão ser confirmados por outros métodos mais específicos (Delincée, 1996).

A fragmentação do DNA é um processo natural que acontece nas células após a morte (apoptose). Este processo também pode ocorrer pelo tratamento com calor, ciclos repetidos de congelamento/descongelamento, assim, os longos períodos de armazenamento podem interferir com os resultados (Cerda, 1998a,b; Delincée, 1996b).

O teste do cometa figura entre os métodos padrões europeus para a detecção de alimentos irradiados (EN 13784) (Delincée, 2002). 


\section{MATERIAIS E MÉTODOS}

\subsection{Amostras}

Foram analisadas as seguintes hortaliças minimamente processadas: alface, acelga, agrião, almeirão, catalônia, couve, escarola, espinafre, repolho. As amostras foram obtidas no comércio varejista da cidade de São Paulo com data de fabricação correspondente ao dia da análise.

\subsection{Irradiação das amostras}

Para o método DEFT/APC, cinco amostras de um mesmo lote de cada hortaliça foram irradiadas na sua própria embalagem, no irradiador multi-propósito tipo compacto de ${ }^{60} \mathrm{Co}$ instalado no IPEN, acondicionadas em recipiente isotérmico com gelox, mantendo a temperatura abaixo de $6^{\circ} \mathrm{C}$. As doses aplicadas foram de $0,5 \mathrm{kGy}$ e $1,0 \mathrm{kGy}$, assim como uma amostra controle. A taxa de dose foi de aproximadamente 3,0 kGy/h. Dosímetros Harwell Gammachrome YR foram utilizados para a medição da dose de radiação.

Para o teste do Cometa, outras cinco amostras de um mesmo lote de cada hortaliça foram irradiadas em sacos para Stomacher, em fonte de ${ }^{60} \mathrm{Co}$ (Gammacell 220) instalado no IPEN, em temperatura ambiente para posterior análise pelo teste do Cometa. As doses aplicadas foram de 0,5kGy e 1,0kGy, assim como uma amostra controle. A taxa de dose foi de 2,55 kGy/h (março/2008). Dosímetros Harwell Amber 3042 foram utilizados para a medição da dose de radiação.

\subsection{Avaliação microbiológica de hortaliças minimamente processadas disponíveis no comércio}

Para a avaliação microbiológica de hortaliças minimamente processadas, disponíveis no comércio, foi realizada a contagem de microrganismos mesófilos aeróbios, psicrotróficos, determinação do número mais provável de coliformes totais e de coliformes fecais (NMP), além da pesquisa de Salmonella spp. 


\subsubsection{Preparação da diluição decimal seriada}

Porções de $25 \mathrm{~g}$ da amostra foram homogeneizadas com $225 \mathrm{~mL}$ de água peptonada (Merck) 0,1\% (acrescida de 0,85\% de $\mathrm{NaCl}$ ) por 1 minuto em velocidade normal em "stomacher" (Seward) e a partir desta primeira diluição $\left(10^{-1}\right)$ foram preparadas diluições decimais seriadas com o mesmo diluente.

\subsubsection{Contagem de microrganismos aeróbios mesófilos (Morton, 2001)}

De cada diluição preparada, $1 \mathrm{~mL}$ foi transferido para uma placa de Petri estéril e adicionado $15 \mathrm{~mL}$ de ágar para contagem padrão (Difco), previamente fundido e resfriado a $47^{\circ} \mathrm{C}\left( \pm 2^{\circ} \mathrm{C}\right)$. Após a homogeneização e solidificação do ágar, as placas foram incubadas em posição invertida a $30^{\circ} \mathrm{C}\left( \pm 1^{\circ} \mathrm{C}\right)$ por $72 \mathrm{~h}$. Após a incubação, foram contadas as placas com 30 a 300 colônias e aplicados os respectivos fatores de correção das diluições; os resultados foram expressos em UFC/g.

\subsubsection{Contagem de microrganismos psicrotróficos (Cousin et al., 2001)}

De cada diluição preparada foi transferido $1,0 \mathrm{~mL}$ para placas de Petri estéreis e adicionado $15 \mathrm{~mL}$ de ágar para contagem padrão (Difco), previamente fundido e resfriado a $47^{\circ} \mathrm{C}\left( \pm 2^{\circ} \mathrm{C}\right)$. Após a homogeneização e solidificação do ágar, as placas foram incubadas em posição invertida a $6-8^{\circ} \mathrm{C}$ por 7 dias. Após a incubação, foram contadas as placas com 15 a 150 colônias e aplicados os respectivos fatores de correção das diluições. Os resultados foram expressos em $\mathrm{UFC} / \mathrm{g}$.

\subsubsection{Determinação do Número Mais Provável de coliformes totais e fecais (Kornacki \& Johnson, 2001)}

De cada diluição preparada, foi transferido $1,0 \mathrm{~mL}$ para cada um dos três tubos contendo tubos de Durham invertidos de uma mesma diluição contendo $9,0 \mathrm{~mL}$ de caldo lactosado lauril sulfato de sódio (Oxoid) e incubados a $37^{\circ} \mathrm{C}$ por $48 \mathrm{~h}$. Após a incubação, de cada tubo que apresentou turvação e produção de gás foi transferida uma alçada para os seguintes meios: ágar Levine (Difco), caldo lactosado com bile e verde brilhante (BVB) (Difco) e caldo Triptona (Difco). As placas contendo ágar Levine foram incubadas a $37^{\circ} \mathrm{C}$ 
por $48 \mathrm{~h}$ e corresponderam à confirmação para coliforme total. Os tubos contendo $9,0 \mathrm{~mL}$ de caldo lactosado com bile e verde brilhante e 5,0mL de caldo Triptona foram incubados a $44,5-45^{\circ} \mathrm{C}$ por $48 \mathrm{~h}$ e corresponderam à confirmação para coliforme fecal. A partir dos tubos que apresentaram turvação e produção de gás no caldo BVB e também se mostraram positivos para indol (após a adição do reativo de Kovac's ao caldo Triptona), foram calculados os respectivos números mais prováveis por grama $(\mathrm{NMP} / \mathrm{g})$, utilizando a tabela de NMP para 3 séries de tubos. Os resultados foram expressos como NMP/g.

\subsubsection{Pesquisa de Salmonella spp. (Andrews et al., 2001)}

A uma porção de $25 \mathrm{~g}$ foi adicionado $225 \mathrm{~mL}$ de água peptonada tamponada $1 \%$ (Merck) (acrescida de $0,85 \%$ de $\mathrm{NaCl}$ ) e incubada a $37^{\circ} \mathrm{C}$ por $24 \mathrm{~h}$ (etapa de préenriquecimento). Após a incubação foi transferido $1,0 \mathrm{~mL}$ para tubos contendo $10 \mathrm{~mL}$ de caldo Rappaport (Merck) e $10 \mathrm{~mL}$ de caldo Selenito Sistina (Merck) e incubado a $41-43^{\circ} \mathrm{C}$ por $24 \mathrm{~h}$ sob agitação leve (etapa de enriquecimento seletivo). Após a incubação, cada caldo foi repicado em ágar SS (Difco) e ágar verde brilhante (BVB) (Difco) e incubados a $37^{\circ} \mathrm{C}$ por $24 \mathrm{~h}$ (etapa de isolamento). De 2 a 4 colônias suspeitas, foram isoladas e confirmadas pelas provas bioquímica em ágar TSI (Difco) e sorologia com soros polivalentes "O" e "H" (Probac do Brasil).

\subsection{Método DEFT/APC}

Este método foi realizado conforme EN 13783 (2001), substituindo o uso de funis pelo suporte de filtro Swinnex (Millipore).

\subsubsection{Pré-tratamento}

Porções de $10 \mathrm{~g}$ da amostra foram homogeneizadas com $90 \mathrm{~mL}$ de água peptonada tamponada (Merck) 0,1\% (acrescida de 0,85\%) por 2 minutos com agitação manual e a partir desta suspensão, foram preparadas diluições decimais seriadas com a mesma solução. Logo 5,0mL das suspensões foram pré-filtradas através de papel de filtro quantitativo de filtragem rápida estéril (porosidade 7,5 micra). 


\subsubsection{Filtração em membrana}

Para filtração em membrana, no interior de um suporte de filtro Swinnex (Millipore) de 25mm, foi colocada uma membrana de policarbonato (Millipore) com poro de $0,6 \mu \mathrm{m}$ com sua parte brilhante voltada para cima e sobre este, um pré-filtro de polipropileno (Millipore) com poro de $11 \mu \mathrm{m}$. O dispositivo foi esterilizado por autoclavagem antes do uso. Um novo dispositivo foi utilizado para cada diluição de cada amostra. De cada suspensão, foram filtrados 2,0mL utilizando uma seringa de plástico descartável estéril. Logo após a filtração, o dispositivo foi aberto e o pré-filtro de $11 \mu \mathrm{m}$ foi descartado.

\subsubsection{Coloração e enxágüe da membrana de filtro DEFT}

O filtro de policarbonato de $0,6 \mu \mathrm{m}$ foi corado com $2,5 \mathrm{~mL}$ de uma solução 0,025\% de alaranjado de acridina por 2 minutos. Logo, o mesmo foi enxaguado com 2,5mL de tampão citrato/ $\mathrm{NaOH}$ de $\mathrm{pH}$ 3,0 e em seguida com 2,5mL de 2-propanol.

\subsubsection{Montagem da lâmina DEFT}

Usando uma pinça, a membrana de $0,6 \mu \mathrm{m}$ foi retirada do dispositivo e deixada secar ao ar. Esta foi colocada com sua parte brilhante voltada para cima sobre uma lâmina de microscopia. Gotas de óleo de imersão foram colocadas embaixo e sobre o filtro e logo uma lamínula foi depositada sobre a membrana.

\subsubsection{Semeadura em profundidade para determinação dos microrganismos aeróbios viáveis (APC)}

A partir das diluições realizadas no item 4.4.1, foi realizada a semeadura em profundidade conforme descrito no item 4.3.2.

\subsubsection{Contagem da lâmina DEFT}

As lâminas DEFT foram examinadas visualmente em um aumento de 1000x sob microscópio de epifluorescência (Zeiss, Axioskop 40) providos de filtro de excitação e 
de barreira de 450-490nm e 515nm, respectivamente. Células com fluorescência alaranjada ou laranja-amareladas foram contadas e os resultados convertidos em microrganismos por grama.

\subsubsection{Cálculo log DEFT/APC $\left(\mathrm{D}_{\mathrm{c}}\right)$}

A contagem DEFT (X) por grama das hortaliças foi calculada usando o número médio de unidades DEFT por campos do microscópio calculado (N/n), o fator do microscópio (FM) e o fator de diluição (FD) da amostra (1). O fator do microscópio foi calculado pela relação entre a área $\left(\mathrm{mm}^{2}\right)$ da membrana de filtro $\left(\mathrm{A}_{\mathrm{f}}\right)$ e o resultado da multiplicação da área $\left(\mathrm{mm}^{2}\right)$ do campo do microscópio $\left(\mathrm{A}_{\mathrm{m}}\right)$ e do volume $(\mathrm{V})(\mathrm{mL})$ de amostra filtrado (2).

$$
\mathrm{X}=(\mathbf{N} \times \mathbf{F M} \times \mathbf{F D}) / \mathbf{n}
$$

$$
\mathbf{F M}=\mathbf{A}_{\mathbf{f}} / \mathbf{A}_{\mathbf{m}} \times \mathbf{V}
$$

$$
\text { Dc }=\text { log contagem DEFT }-\log \text { contagem APC }
$$

Cada unidade DEFT correspondia àquelas bactérias únicas ou agrupadas, com fluorescência alaranjada ou laranja-amareladas (FIG. 14). Em uma lâmina com uma quantidade de unidades DEFT inferior a vinte por campo do microscópio, foram contados vinte campos do microscópio; aquelas lâminas com uma quantidade superior a vinte e inferior a 100 unidades DEFT, foram contados dez campos e; aquelas lâminas que apresentaram mais de 100 unidades DEFT foi utilizada a próxima diluição.

O resultado foi expresso como a diferença entre o log da contagem DEFT e o $\log$ da contagem APC (3).

\subsection{Teste do Cometa}

Este teste foi realizado conforme o protocolo alcalino descrito por G. Koppen (1997). 


\subsubsection{Preparação das lâminas com a primeira agarose (agarose low melting, 1,5\%)}

Foram colocadas 2 gotas de low melting agarose $1,5 \%\left(\mathrm{p} / \mathrm{v}\right.$ em $\left.\mathrm{H}_{2} 0\right)$ a $45^{\circ} \mathrm{C}$ sobre a lâmina. A agarose foi puxada com outra lâmina e foi deixada secar a temperatura ambiente. As lâminas foram rotuladas.

\subsubsection{Preparação da suspensão de células das amostras}

Quatro folhas pequenas de cada hortaliça em estudo, foram maceradas em um morteiro com 5,0mL de PBS $\left(0,1 \mathrm{M} \mathrm{NaCl}, 2,7 \mathrm{mM} \mathrm{KCl}, 10 \mathrm{mM} \mathrm{Na}_{2} \mathrm{HPO}_{4}, 1,5 \mathrm{mM} \mathrm{KH}_{2} \mathrm{PO}_{4}\right.$, pH 7,4) acrescido de 1mM EDTA.

\subsubsection{Preparação do gel com células}

Foram misturados $90 \mu \mathrm{L}$ da suspensão de células com $600 \mu \mathrm{L}$ de low melting agarose $0,8 \%\left(\mathrm{p} / \mathrm{v}\right.$ em $\left.\mathrm{H}_{2} \mathrm{O}\right)$ a $45^{\circ} \mathrm{C}$. Desta mistura, $100 \mu \mathrm{L}$ foram rapidamente pipetados sobre uma lâmina com a primeira agarose 1,5\% (utilizada para promover a aderência da segunda camada). Sobre esta lâmina foi colocada uma lamínula evitando a formação de bolhas de ar e colocada sobre suporte com gelo por 5 minutos para solidificar. Decorridos os 5 minutos a lamínula foi retirada. Para cada amostra e para cada dose foram preparadas três lâminas.

\subsubsection{Lise das células}

As lâminas foram imersas em solução de lise contendo 2,5\% (p/v) de dodecil sulfato de sódio em 45mM TBE (45mM Tris base, $45 \mathrm{mM} \mathrm{H}_{3} \mathrm{BO}_{3}, 1 \mathrm{mM}$ EDTA, pH 8,4) e incubadas sob agitação lenta por 1 hora a $4^{\circ} \mathrm{C}$. Após uma hora de incubação, as lâminas foram enxaguadas com $\mathrm{H}_{2} \mathrm{O}$ destilada e lavadas por 10 minutos. Este passo e os subseqüentes foram conduzidos sob luz fraca para prevenir danos adicionais no DNA.

\subsubsection{Desnaturação}

As lâminas foram imersas na solução de desnaturação (300mM NaOH, 1mM EDTA, pH>13) e incubadas sob agitação lenta por 20 minutos a $4^{\circ} \mathrm{C}$. 


\subsubsection{Eletroforese}

As lâminas foram colocadas lado a lado na câmara de eletroforese preenchida com 45mM TBE por 10 minutos. Logo foi realizada a corrida eletroforética por 3,5 minutos a $25 \mathrm{~V}$ e $340 \mathrm{~mA}$. Após a corrida, as lâminas foram lavadas duas vezes com $\mathrm{H}_{2} \mathrm{O}$ destilada por 5 minutos e secas na estufa por 20 minutos a $37^{\circ} \mathrm{C}$.

\subsubsection{Coloração}

As lâminas foram imersas na solução de alaranjado de acridina $(5,0 \mu \mathrm{L} / \mathrm{mL}$ em PBS, pH 7,4) por 5 minutos e finalmente lavadas com $\mathrm{H}_{2} \mathrm{O}$ destilada por 1 minuto. Foi colocada uma lamínula sobre a lâmina ainda úmida.

\subsubsection{Contagem}

Para visualização do dano ao DNA, cada lâmina foi examinada em um aumento de 400X com uma objetiva de 40X sob microscópio de fluorescência (Zeiss, Axioskop) equipado com filtro de excitação de 450-490nm e de barreira de 515nm. Foram analisadas 100 células aleatórias por dose e classificadas por observação visual de acordo com a escala da FIG. 1, seguindo padronização estabelecida em publicações anteriores (Araújo et al., 2004; Villavicencio et al., 2004, 2007).
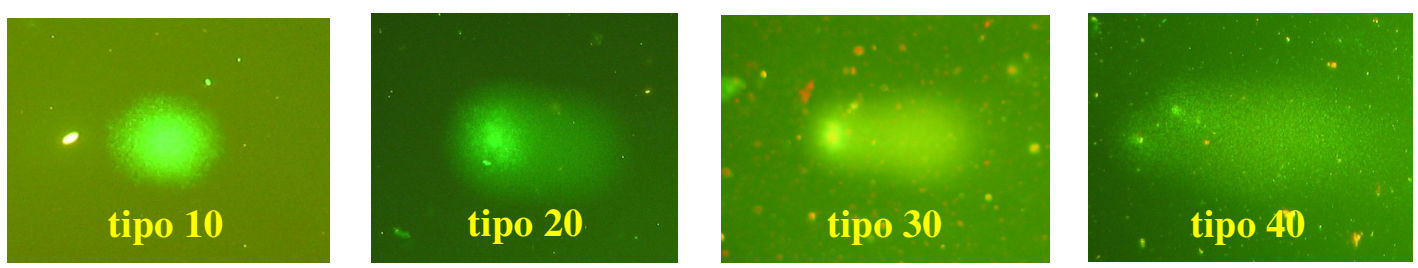

FIGURA 1 - Fotomicrografias de diferentes tipos de cometas após o processo de irradiação (aumento de 400X).

\subsection{Análise Estatística}

A análise estatística foi realizada usando GraphPad Prism, versão 4.00. As diferenças entre as médias foram determinadas por análise de variância a um nível de significância de 5\%, seguida pelo teste de Dunnett. 


\section{RESULTADOS E DISCUSSÃO}

\subsection{Avaliação microbiológica de hortaliças minimamente processadas disponíveis} no comércio

A avaliação microbiológica das hortaliças minimamente processadas analisadas revelou elevadas populações para os diversos grupos de microrganismos pesquisados (TAB.1 e FIG. 2, 3, 4). Nas amostras controle, os microrganismos aeróbios mesófilos apresentaram populações que variaram entre $2,5 \times 10^{6}$ e $4,2 \times 10^{7} \mathrm{UFC} / \mathrm{g}$ para

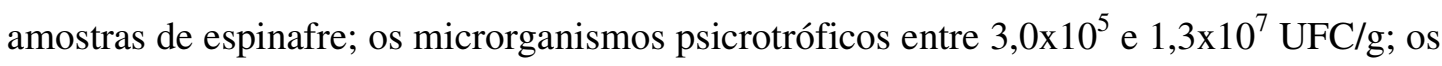
coliformes totais entre $2,4 \times 10^{3}$ e $2,4 \times 10^{5} \mathrm{NMP} / \mathrm{g}$. SZABO et al. (2000) também encontraram populações elevadas de microrganismos aeróbios totais em amostras de alface minimamente processadas, entre $10^{3}$ e $10^{9} \mathrm{UFC} / \mathrm{g}$, tendo $73 \%$ das amostras populações entre $10^{5}$ e $10^{7} \mathrm{UFC} / \mathrm{g}$.

Não foram detectados coliformes fecais (<3 NMP/g) e Salmonella spp. (em $25 \mathrm{~g}$ ) em todas as hortaliças analisadas. Estes resultados qualificam as hortaliças analisadas em acordo com a Resolução RDC n 12 de 02 de janeiro de 2001 (ANVISA), que estabelece para hortaliças "in natura" a ausência de Salmonella (em 25g), visando a preservação da saúde pública.

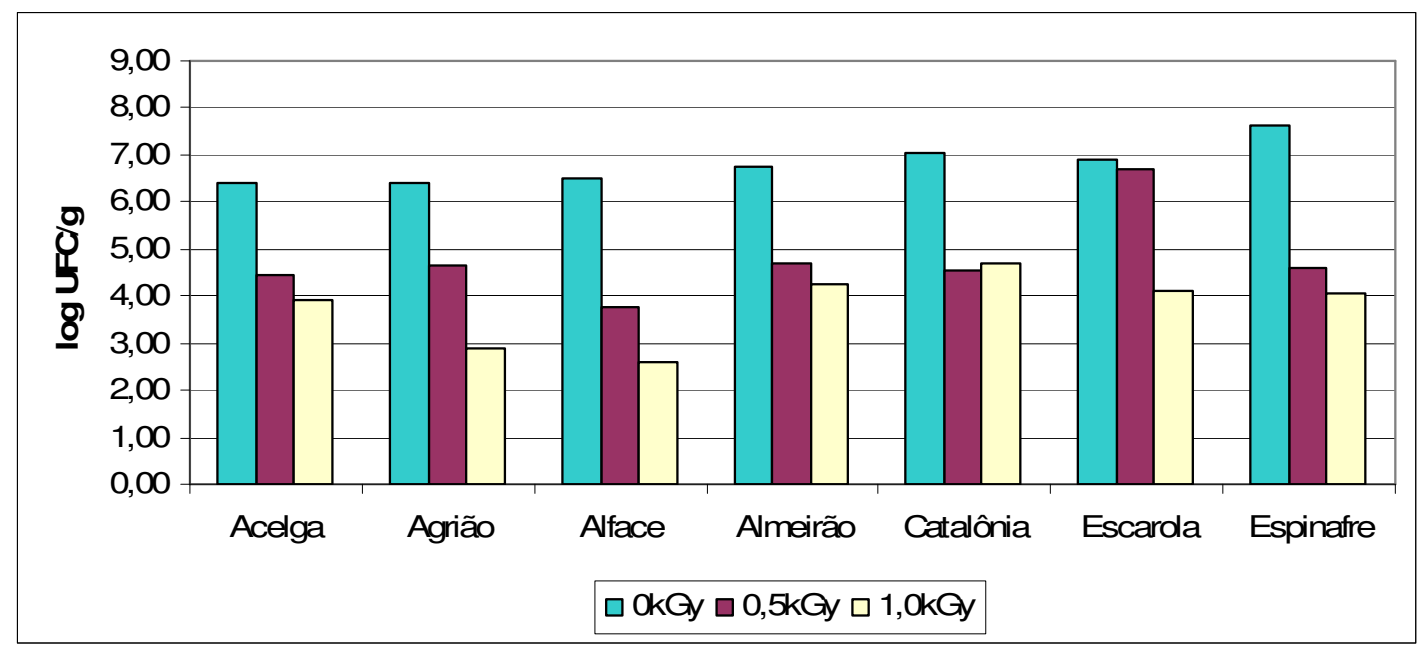

FIGURA 2 - Contagens de microrganismos aeróbios mesófilos (média log UFC/g) presentes em amostras de hortaliças minimamente processadas adquiridas no comércio varejista da cidade de São Paulo tratadas por radiação (09/2007 a 01/2008). 
TABELA 1 - Resultados da análise microbiológica (média das contagens) obtidas de hortaliças minimamente processadas adquiridas no comércio varejista da cidade de São Paulo, antes e depois do tratamento por radiação (09/2007 a 01/2008).

Microrganismos

\begin{tabular}{|c|c|c|c|c|c|c|}
\hline Amostra & $\begin{array}{c}\text { Dose } \\
(\mathrm{kGy})\end{array}$ & $\begin{array}{c}\text { Mesófilos } \\
\text { (UFC/g) }\end{array}$ & $\begin{array}{l}\text { Psicrotróficos } \\
\text { (UFC/g) }\end{array}$ & $\begin{array}{c}\text { Coliformes } \\
\text { totais } \\
(\mathrm{NMP} / \mathrm{g})\end{array}$ & $\begin{array}{c}\text { Coliformes } \\
\text { fecais } \\
(\mathrm{NMP} / \mathrm{g})\end{array}$ & $\begin{array}{c}\text { Salmonella spp } \\
\quad(\mathrm{em} 25 \mathrm{~g})\end{array}$ \\
\hline \multirow{3}{*}{ Acelga } & $\mathbf{0}$ & $2,5 \times 10^{6}$ & $3,1 \times 10^{6}$ & $2,1 \times 10^{4}$ & $<3$ & Ausente \\
\hline & 0,5 & $2,8 \times 10^{4}$ & $2,8 \times 10^{3}$ & $<3$ & $<3$ & Ausente \\
\hline & 1,0 & $8,3 \times 10^{3}$ & $7,4 \times 10^{2}$ & $<3$ & $<3$ & Ausente \\
\hline \multirow{3}{*}{ Agrião } & 0 & $2,5 \times 10^{6}$ & $7,9 \times 10^{5}$ & $\geq 2,4 \times 10^{5}$ & $<3$ & Ausente \\
\hline & 0,5 & $4,3 \times 10^{4}$ & $4,9 \times 10^{4}$ & $2,4 \times 10^{2}$ & $<3$ & Ausente \\
\hline & 1,0 & $8,1 \times 10^{2}$ & $6,7 \times 10^{2}$ & $<3$ & $<3$ & Ausente \\
\hline \multirow{3}{*}{ Alface } & $\mathbf{0}$ & $3,1 \times 10^{6}$ & $3,3 \times 10^{6}$ & $2,4 \times 10^{5}$ & $<3$ & nd \\
\hline & 0,5 & $5,7 \times 10^{3}$ & $1,0 \times 10^{4}$ & $<3$ & $<3$ & nd \\
\hline & 1,0 & $4,1 \times 10^{2}$ & $5,9 \times 10^{3}$ & $<3$ & $<3$ & nd \\
\hline \multirow{3}{*}{ Almeirão } & 0 & $5,5 \times 10^{6}$ & $1,3 \times 10^{7}$ & $\geq 2,4 \times 10^{5}$ & $<3$ & Ausente \\
\hline & 0,5 & $4,9 \times 10^{4}$ & $1,0 \times 10^{4}$ & $4,3 \times 10$ & $<3$ & Ausente \\
\hline & 1,0 & $1,9 \times 10^{4}$ & $3,3 \times 10^{3}$ & $<3$ & $<3$ & Ausente \\
\hline \multirow{3}{*}{ Catalônia } & $\mathbf{0}$ & $1,1 \times 10^{7}$ & $3,0 \times 10^{5}$ & $4,6 \times 10^{4}$ & $<3$ & Ausente \\
\hline & 0,5 & $3,6 \times 10^{4}$ & $9,5 \times 10^{4}$ & $<3$ & $<3$ & Ausente \\
\hline & 1,0 & $5,1 \times 10^{4}$ & $8,5 \times 10^{2}$ & $<3$ & $<3$ & Ausente \\
\hline \multirow{3}{*}{ Escarola } & $\mathbf{0}$ & $8,0 \times 10^{6}$ & $3,1 \times 10^{6}$ & $7,5 \times 10^{4}$ & $<3$ & Ausente \\
\hline & 0,5 & $4,9 \times 10^{6}$ & $7,4 \times 10^{3}$ & $<3$ & $<3$ & Ausente \\
\hline & 1,0 & $1,3 \times 10^{4}$ & $9,9 \times 10^{2}$ & $<3$ & $<3$ & Ausente \\
\hline \multirow{3}{*}{ Espinafre } & 0 & $4,2 \times 10^{7}$ & $1,1 \times 10^{7}$ & $\geq 2,4 \times 10^{3}$ & $<3$ & Ausente \\
\hline & 0,5 & $3,9 \times 10^{4}$ & $4,4 \times 10^{4}$ & $2,3 \times 10$ & $<3$ & Ausente \\
\hline & 1,0 & $1,2 \times 10^{4}$ & $6,1 \times 10^{3}$ & $<3$ & $<3$ & Ausente \\
\hline
\end{tabular}

nd $=$ sem dados

Segundo Franco \& Landgraf (1996), ainda que os patógenos estejam ausentes e que não tenham ocorrido alterações nas condições organolépticas do alimento, um número elevado de microrganismos aeróbios mesófilos (em geral superior a $10^{6} \mathrm{UFC} / \mathrm{g}$ ) e psicrotróficos pode indicar que o alimento é insalubre. Em alimentos perecíveis, esta condição pode ser indicativa de que ocorreu abuso durante o armazenamento em relação ao 
binômio tempo/temperatura. Vale ainda ressaltar, que todas as bactérias patogênicas de origem alimentar são mesófilas. Logo, elevadas populações destes microrganismos significa que houve condições para que estes patógenos se multiplicassem.

Embora não existam, na legislação brasileira vigente (Resolução RDC n ${ }^{\circ} 12$ de 02/01/01 - ANVISA), padrões para bactérias psicrotróficas e coliformes totais em hortaliças minimamente processadas, tem sido preconizado que alimentos contendo contagens microbianas superiores a $10^{5}$ a $10^{6} \mathrm{UFC} / \mathrm{g}$ podem ser impróprios para consumo humano, devido à perda de valor nutricional, alterações organolépticas, riscos de deterioração e toxinfecções (Caruso \& Camargo, 1984).

As amostras irradiadas com $0,5 \mathrm{kGy}$ mostraram uma diminuição da população dos microrganismos pesquisados (FIG. 2, 3, 4). As populações dos aeróbios mesófilos

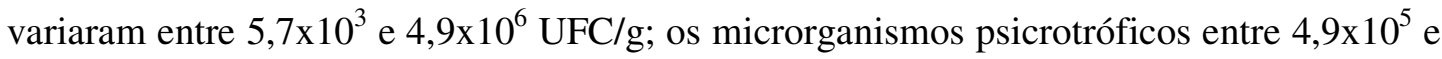
$9,5 \times 10^{4} \mathrm{UFC} / \mathrm{g}$; os coliformes totais alcançaram um valor máximo $2,4 \times 10^{2} \mathrm{NMP} / \mathrm{g}$ para o agrião e, inclusive deixaram de ser detectados ( $<3 \mathrm{NMP} / g)$ para acelga, alface, catalônia e escarola. Esta redução significativa das contagens de coliformes totais, mesmo com uma dose de apenas $0,5 \mathrm{kGy}$, pode decorrer do fato de este grupo condensar bactérias da família Enterobacteriaceae, bacilos gram-negativos. É sabido que bactérias gram-negativas são mais radiosensíveis que as gram-positivas (Jay, 2001). Não foram detectados coliformes fecais ( $<3 \mathrm{NMP} / \mathrm{g}$ ) e Salmonella spp. (em 25g) para todas as amostras estudadas.

Em estudo sobre os efeitos combinados do processamento por irradiação e do empacotamento com atmosfera modificada com amostras de couve chinesa, Ahn et al. (2005) também obtiveram uma redução significativa nas populações iniciais de bactérias aeróbias quando irradiadas com raios gama com doses iguais ou superiores a 0,5kGy, alcançando uma redução de 2-3log UFC/g. 


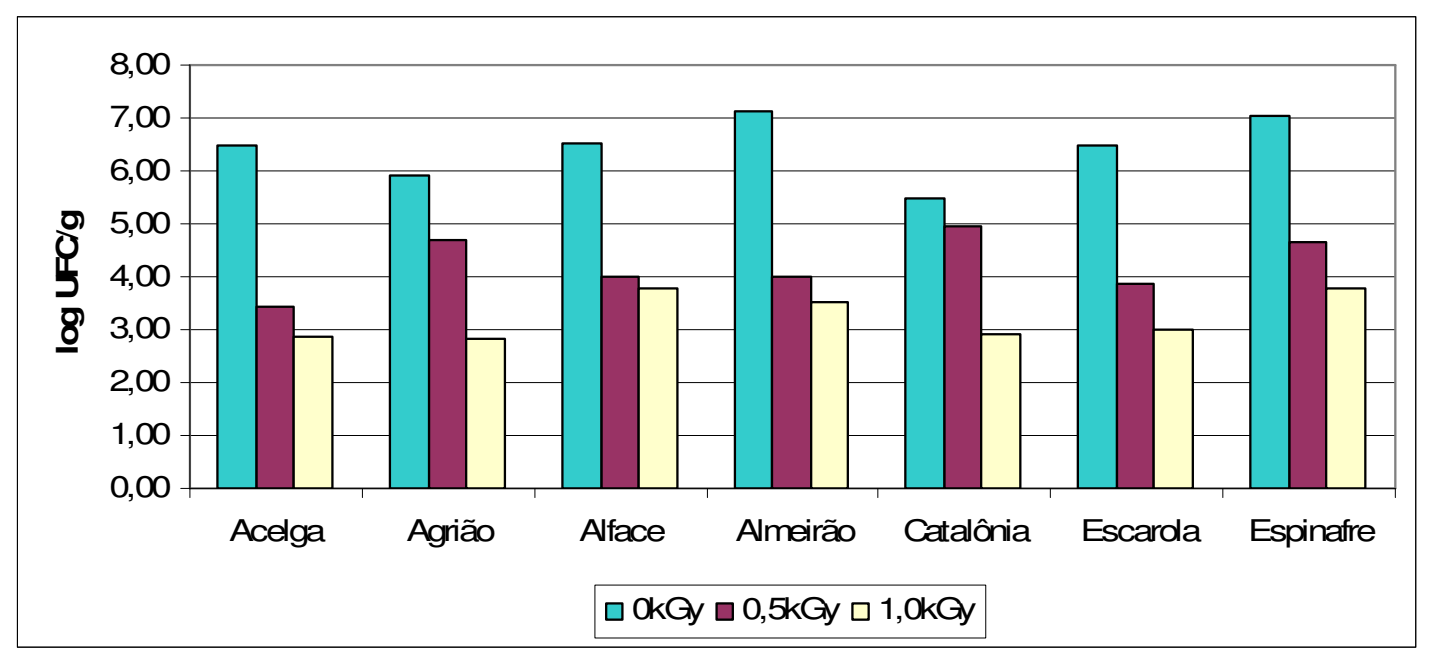

FIGURA 3 - Contagens de microrganismos psicrotróficos (média log UFC/g) presentes em amostras de hortaliças minimamente processadas adquiridas no comércio varejista da cidade de São Paulo tratadas por radiação (09/2007 a 01/2008).

Similar decréscimo nas contagens obtidas foram verificados para as amostras

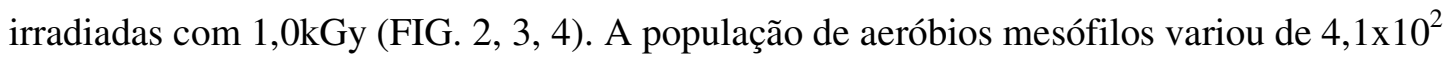

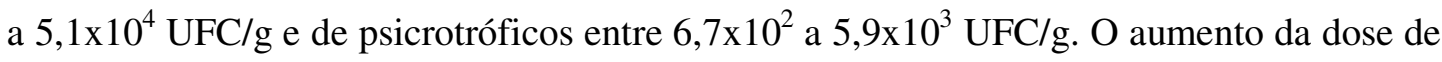
radiação promoveu um grande decréscimo da população de coliformes totais, não sendo mais detectados $(<3 \mathrm{NMP} / \mathrm{g})$. De igual maneira, todas as amostras apresentaram resultados $<3 \mathrm{NMP} / \mathrm{g}$ de coliformes fecais e foi verificada a ausência de Salmonella spp. (em 25g).

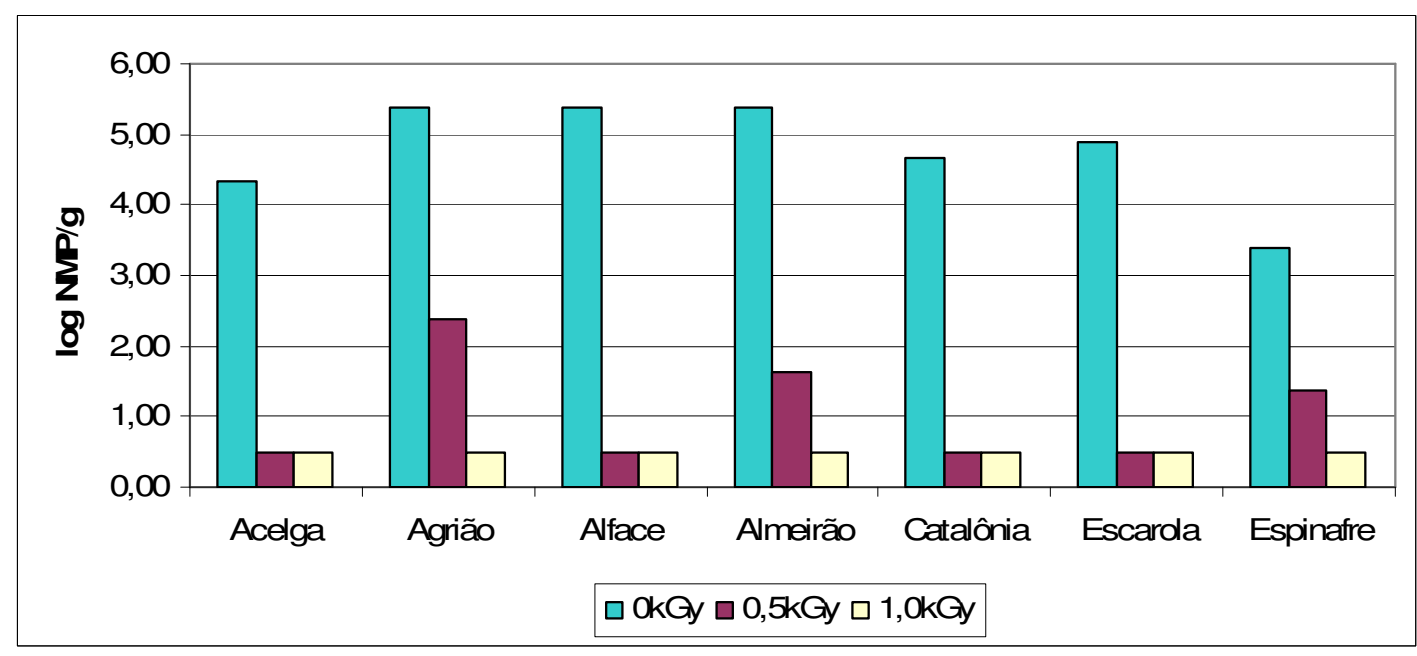

FIGURA 4 - Contagens de coliformes totais (média log UFC/g) presentes em amostras de hortaliças minimamente processadas adquiridas no comércio varejista da cidade de São Paulo tratadas por radiação (09/2007 a 01/2008). 
Em geral, as hortaliças minimamente processadas estudadas no presente trabalho apresentaram populações de mesófilos entre $10^{6}$ e $10^{8}$, ainda depois de terem sofrido o processamento mínimo. Uma vez irradiadas, a dose de $0,5 \mathrm{kGy}$ foi insuficiente para reduzir em 3 log a contagem inicial, objetivo este apenas alcançado quando tratadas com uma dose de $1,0 \mathrm{kGy}$.

Estes resultados são comparáveis com diversos estudos que avaliaram o efeito do tratamento por radiação na redução microbiana de vegetais minimamente processados, apresentados na revisão bibliográfica.

Diversos fatores aumentam a sensibilidade dos microrganismos, principalmente a presença do oxigênio e o alto teor de água de um alimento. Estes fatores potencializam o efeito indireto da radiação, provocando a radiólise da água, formando radicais livres que podem promover alterações letais nos seres vivos. Entretanto, as diferentes condições de embalagem das hortaliças minimamente processadas, como por exemplo, em atmosfera modificada, podem alterar os efeitos da radiação (Franco \& Landgraf, 1996). Os dados obtidos indicam que o processamento por irradiação com uma dose de 1kGy garantiu a redução de pelo menos 2 ciclos logarítmicos para os microrganismos estudados.

Considerando que o processamento mínimo por si só não garante níveis seguros de microrganismos patogênicos, o risco destas bactérias em vegetais minimamente processados pode ser reduzido pelo tratamento por radiação, aumentando desta forma a segurança do consumidor.

Vale ainda ressaltar, que baixas doses de radiação, associadas ao processamento mínimo de hortaliças, ao mesmo tempo em que contribuem para o aumento da segurança microbiológica, em geral não prejudicam os atributos sensoriais destes alimentos, conforme foi relatado por diversos autores. Martins et al. (2004), avaliando os efeitos da radiação gama em agrião minimamente processado, verificaram que a aceitabilidade de amostras não irradiadas e amostras de agrião irradiadas com dose igual a $1 \mathrm{kGy}$ foi superior a aquela obtidas com doses maiores. Goularte et al. (2004) demonstraram que os atributos sensoriais de amostras de alface irradiadas com 0,7 e 0,9kGy não foram afetadas com o tratamento por radiação. 
5.2 Detecção do processamento por irradiação pelo método DEFT/APC

Os resultados de log DEFT e de log APC para as amostras de hortaliças minimamente processadas tratadas ou não por irradiação se encontram na TAB. 2.

TABELA 2 - Contagem DEFT, contagem APC e Dc de hortaliças minimamente processadas adquiridas no comércio da cidade de São Paulo após o processo de irradiação.

\begin{tabular}{|c|c|c|c|c|}
\hline \multirow{2}{*}{ Amostras } & & \multicolumn{3}{|c|}{ Dose de radiação (kGy) } \\
\hline & & $\mathbf{0}$ & $\mathbf{0 , 5}$ & 1,0 \\
\hline \multirow{3}{*}{ Acelga } & $\log$ DEFT & 6,38 & 6,29 & 6,63 \\
\hline & $\log$ APC & 7,18 & 4,32 & 4,40 \\
\hline & Dc & $-0,79$ & 1,97 & 2,23 \\
\hline \multirow{3}{*}{ Agrião } & $\log$ DEFT & 6,62 & 6,62 & 6,56 \\
\hline & $\log \mathbf{A P C}$ & 7,11 & 5,00 & 4,63 \\
\hline & Dc & $-0,49$ & 1,62 & 1,92 \\
\hline \multirow{3}{*}{ Alface } & $\log$ DEFT & 6,29 & 5,69 & 5,70 \\
\hline & $\log$ APC & 6,49 & 3,76 & 2,61 \\
\hline & Dc & $-0,20$ & 1,94 & 3,08 \\
\hline \multirow{3}{*}{ Almeirão } & $\log$ DEFT & 6,29 & 6,57 & 6,38 \\
\hline & $\log$ APC & 7,04 & 4,90 & 4,28 \\
\hline & Dc & $-0,75$ & 1,67 & 2,10 \\
\hline \multirow{3}{*}{ Catalônia } & $\log$ DEFT & 6,48 & 6,16 & 6,26 \\
\hline & $\log \mathbf{A P C}$ & 6,94 & 5,15 & 4,86 \\
\hline & Dc & $-0,46$ & 1,02 & 1,41 \\
\hline \multirow{3}{*}{ Escarola } & $\log$ DEFT & 6,03 & 5,89 & 6,42 \\
\hline & $\log$ APC & 6,08 & 4,28 & 4,11 \\
\hline & Dc & $-0,05$ & 1,61 & 2,31 \\
\hline \multirow{3}{*}{ Espinafre } & $\log$ DEFT & 6,50 & 6,59 & 6,59 \\
\hline & $\log$ APC & 7,62 & 4,59 & 4,08 \\
\hline & Dc & $-1,12$ & 2,00 & 2,51 \\
\hline \multirow{3}{*}{ Repolho } & $\log$ DEFT & 6,51 & 6,56 & 6,54 \\
\hline & $\log$ APC & 7,26 & 4,84 & 2,92 \\
\hline & Dc & $-0,75$ & 1,72 & 3,62 \\
\hline
\end{tabular}


Antes da irradiação, as contagens obtidas usando o método DEFT e o APC se correlacionam bem. Em geral, com o incremento das doses de radiação, os valores de log DEFT se mantiveram na mesma faixa de valores $(\mathrm{p}>0,05)$ enquanto os valores encontrados para log APC reduziram. Diferentemente dos valores de log DEFT, os valores de log APC diminuíram gradualmente com as doses de 0,5kGy e 1,0kGy. Assim, o valor log (DEFT/APC) aumentou gradativamente com doses de radiação crescentes.

O cálculo log (DEFT/APC) foi determinado para cada amostra de hortaliça. Em todas as amostras estudadas, o resultado da subtração entre log DEFT e log APC aumentou paralelamente com doses de radiação crescentes (FIG. 5, 6, 7, 8, 9, 10, 11, 12).

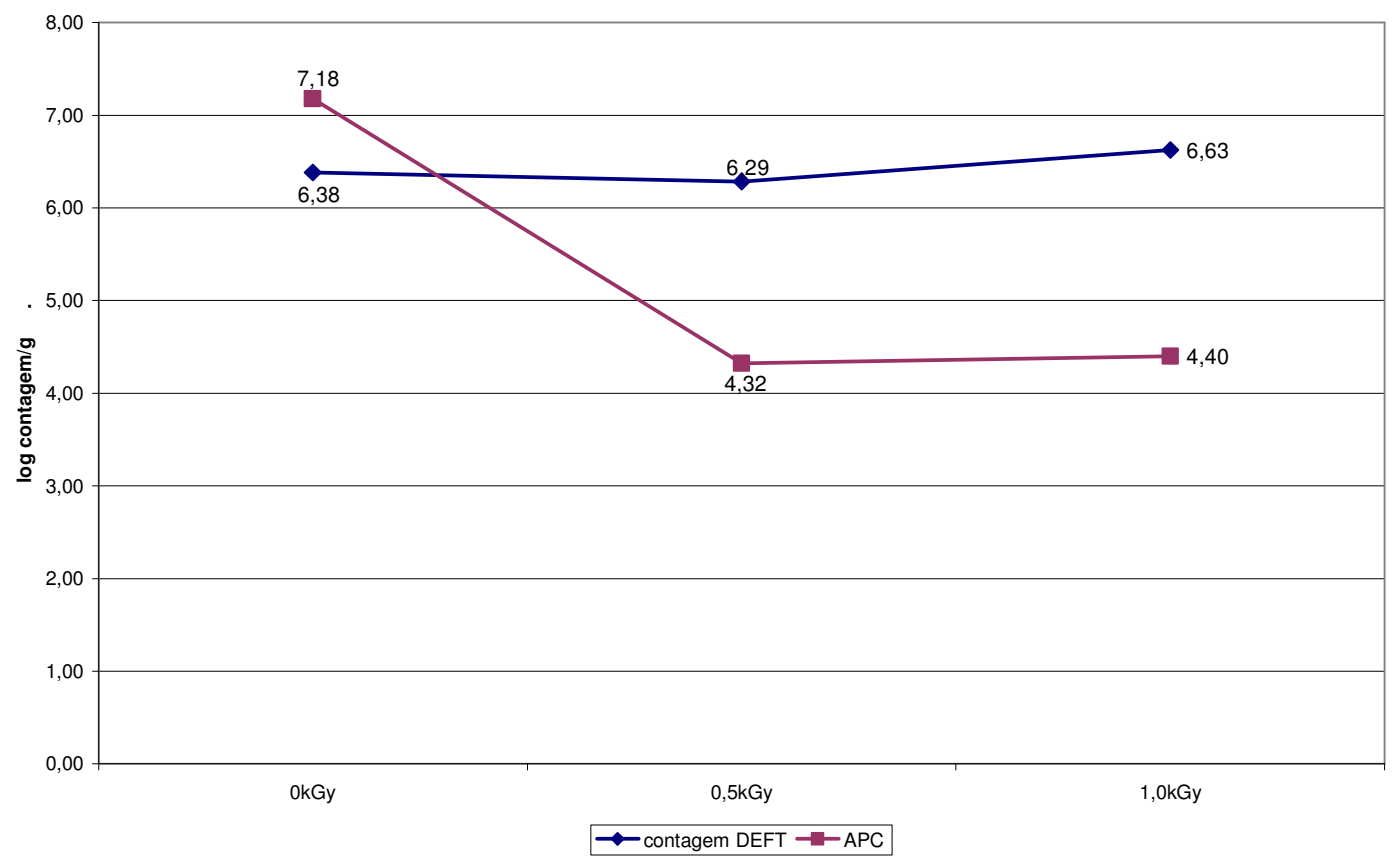

FIGURA 5 - Efeito da irradiação nas contagens DEFT e APC de acelga. 


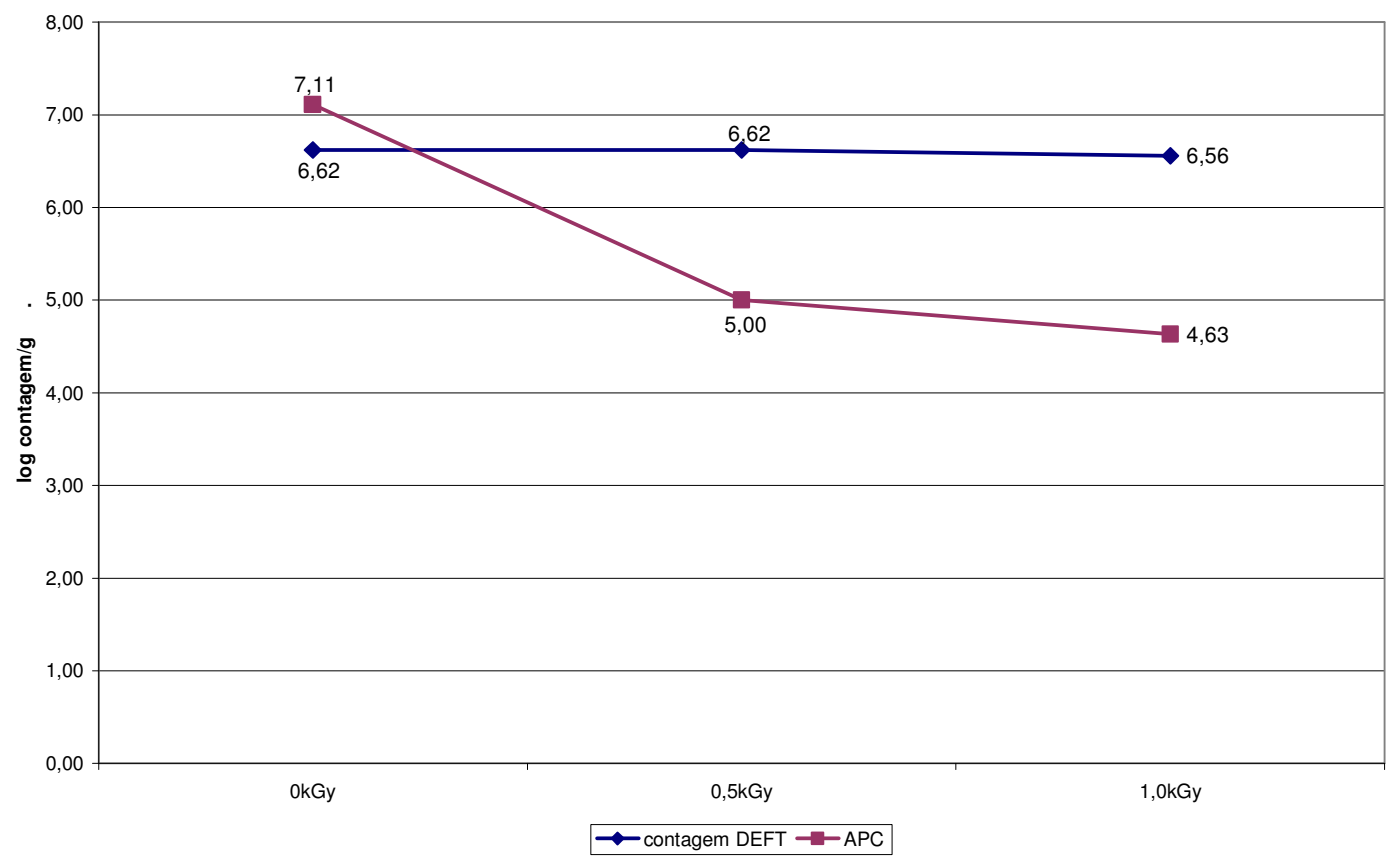

FIGURA 6 - Efeito da irradiação nas contagens DEFT e APC de agrião.

Quando as hortaliças foram irradiadas com 0,5kGy, o tratamento teve um efeito limitado na contagem de microrganismos mesófilos viáveis (APC) das amostras. O processamento por irradiação das amostras de agrião, almeirão, escarola e repolho com uma dose de 0,5kGy mostraram valores $\log$ (DEFT/APC) de pelo menos 1,61 log; ainda assim, não ultrapassaram a marca de $2 \log$ (FIG. 6, 8, 10, 12). As amostras de catalônia irradiadas com 0,5kGy foram as únicas a apresentarem $\log$ (DEFT/APC) de 1 unidade logarítmica (FIG. 9). As demais hortaliças tratadas com a mesma dose mostraram valores $\log (\mathrm{DEFT} / \mathrm{APC})$ na faixa de 1,94 e 2,00 log. 


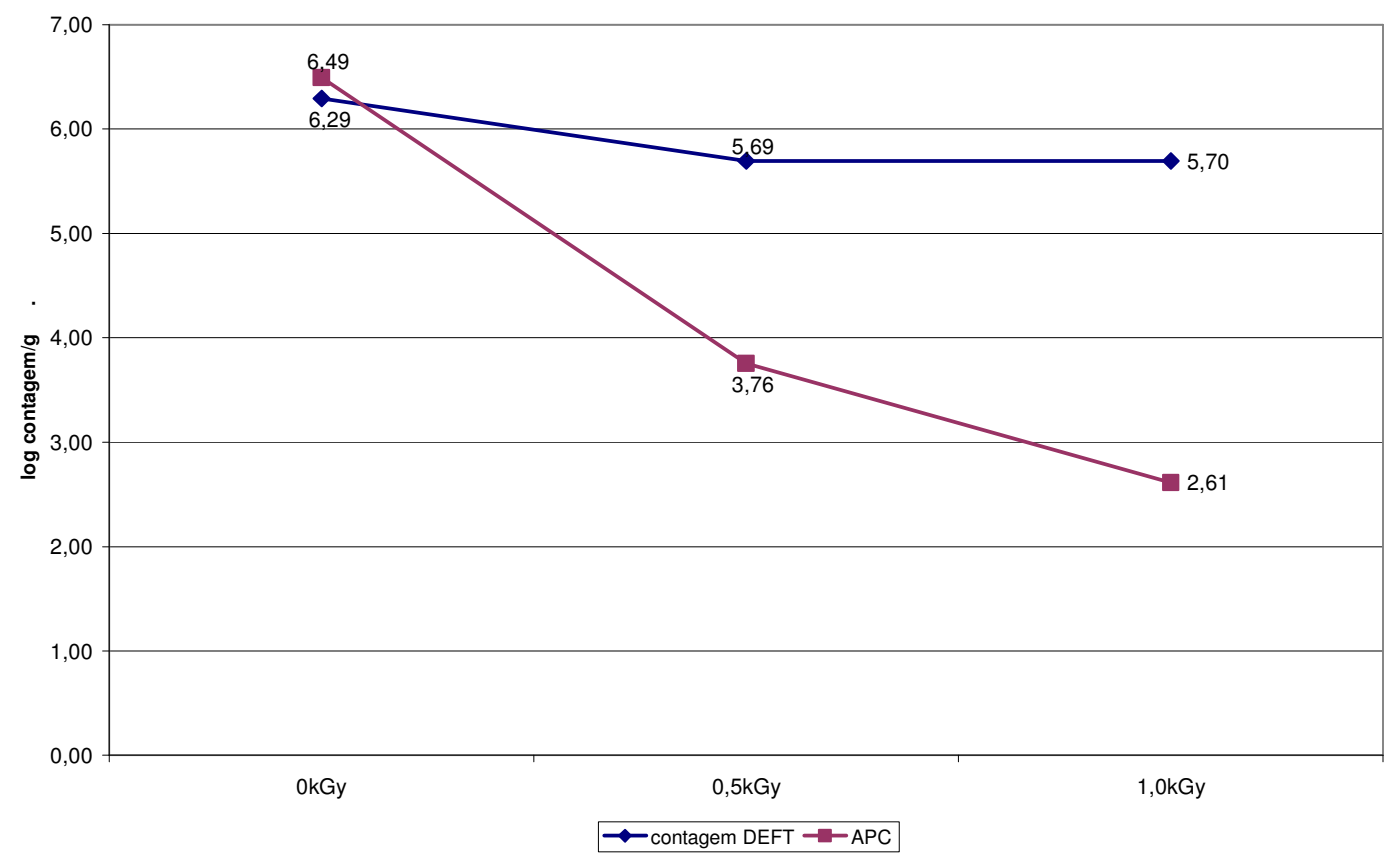

FIGURA 7 - Efeito da irradiação nas contagens DEFT e APC de alface.

Quando as hortaliças foram tratadas com uma dose maior, e 1,0kGy foi aplicado as mesmas, a irradiação teve um efeito maior na contagem APC. As amostras de alface e repolho irradiadas com esta dose alcançaram as maiores diferenças, resultando respectivamente nos valores de 3,08 e 3,62 log (FIG. 7, 12). Estes valores observados, respectivamente próximos a 3 e $4 \log$ são resultados de uma baixa contagem de microrganismos viáveis nestas amostras. De igual maneira, as hortaliças agrião, almeirão, acelga, escarola e espinafre apresentaram elevados valores log (DEFT/APC), estando compreendidos na faixa de 1,92 e 2,51 log (FIG. 6, 8, 5, 10, 11). 


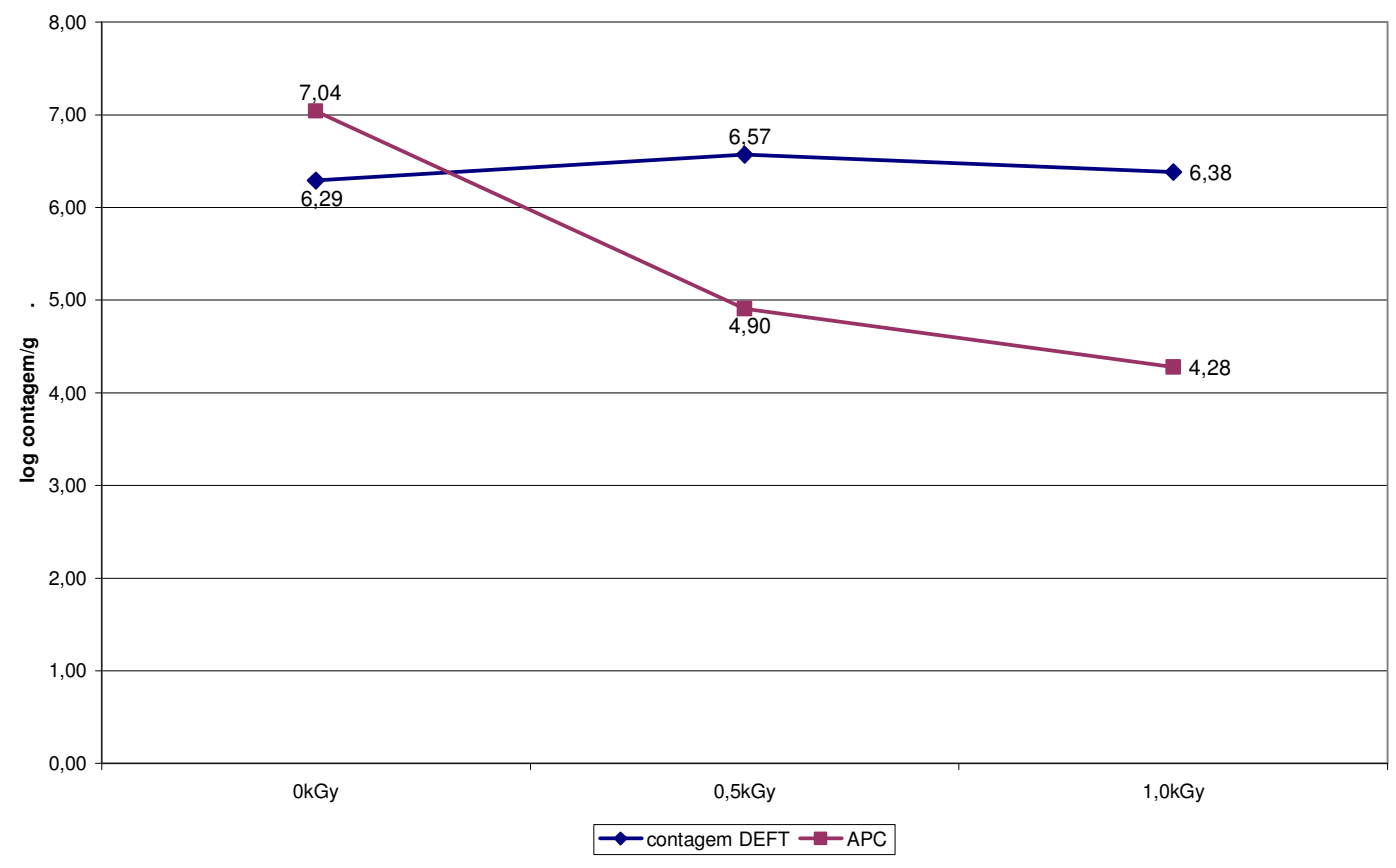

FIGURA 8 - Efeito da irradiação nas contagens DEFT e APC de almeirão.

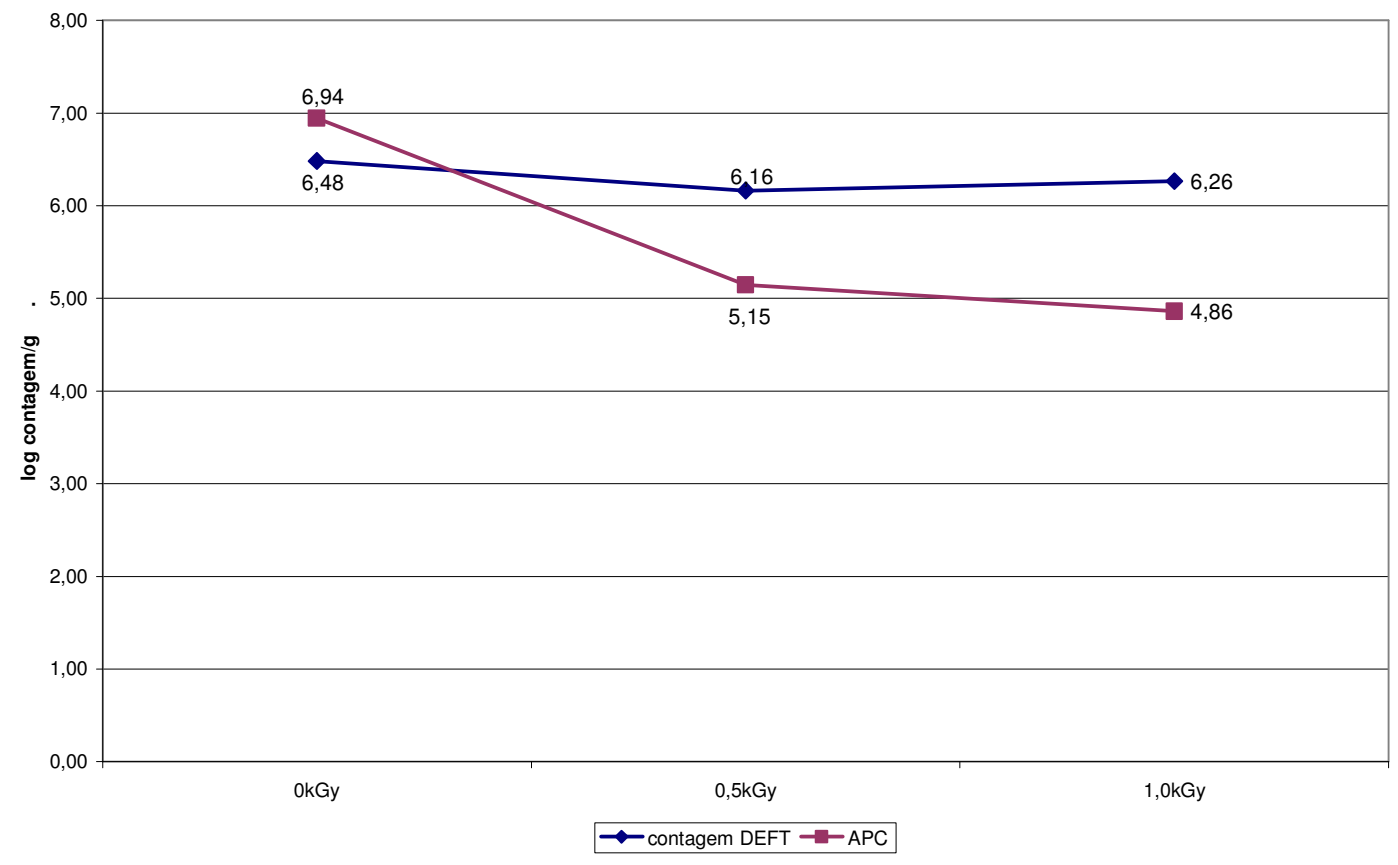

FIGURA 9 - Efeito da irradiação nas contagens DEFT e APC de catalônia.

Por outro lado, mesmo quando tratadas com 1,0kGy, as amostras de catalônia não alcançaram o valor de 1,5 log (FIG. 9). Este fato pode ser decorrente de uma baixa contagem inicial das amostras analisadas. 


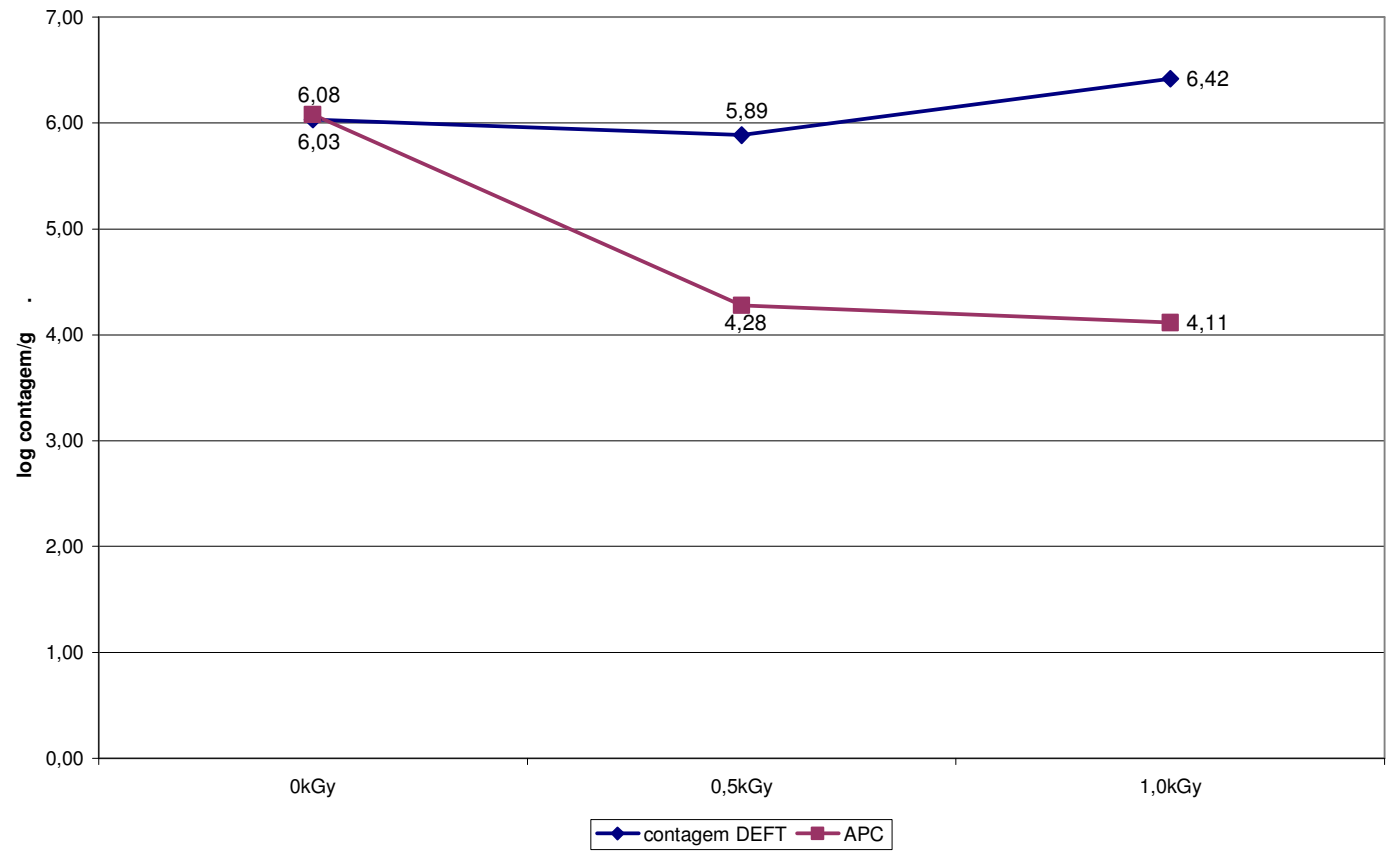

FIGURA 10 - Efeito da irradiação nas contagens DEFT e APC de escarola.

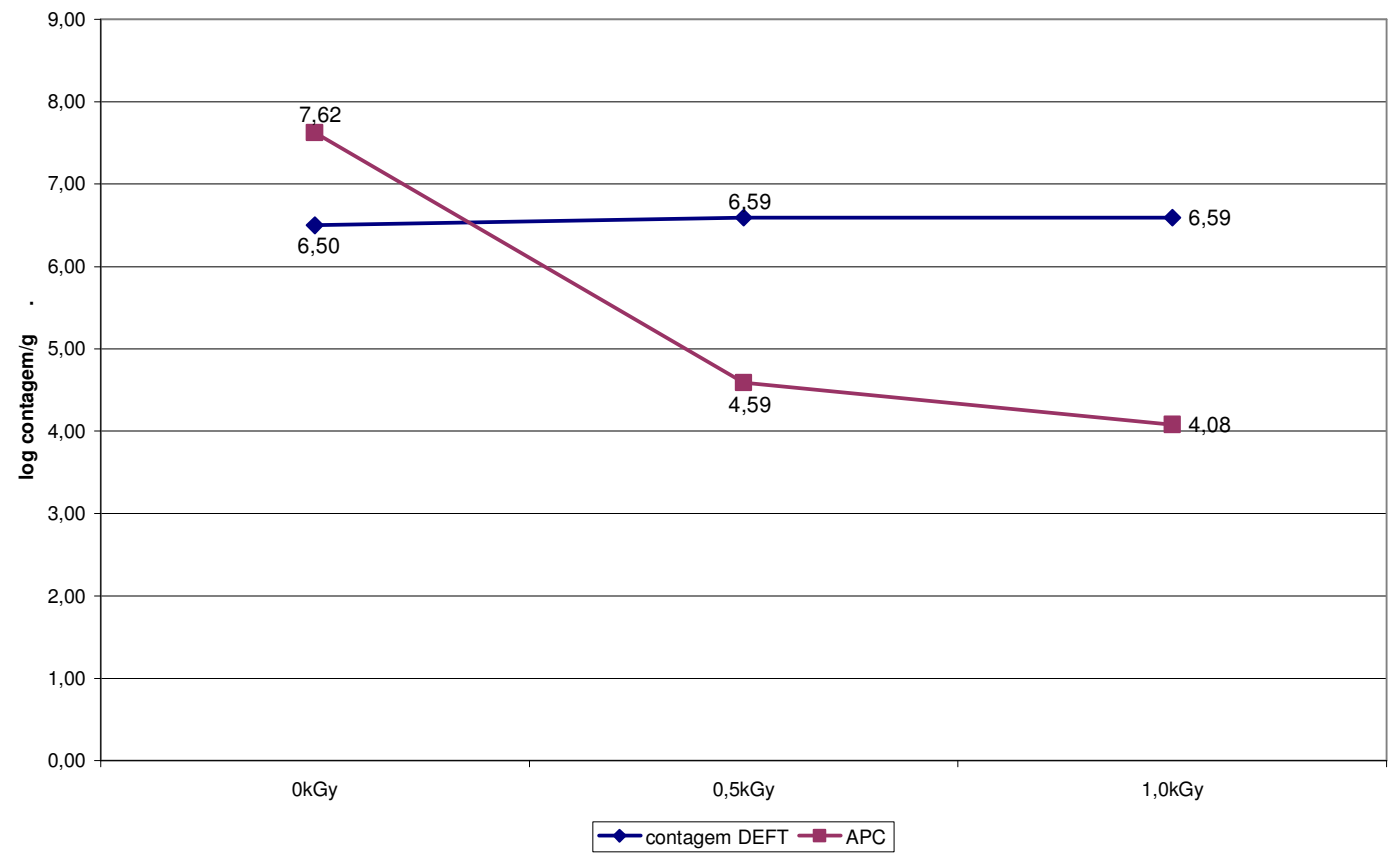

FIGURA 11 - Efeito da irradiação nas contagens DEFT e APC de espinafre. 


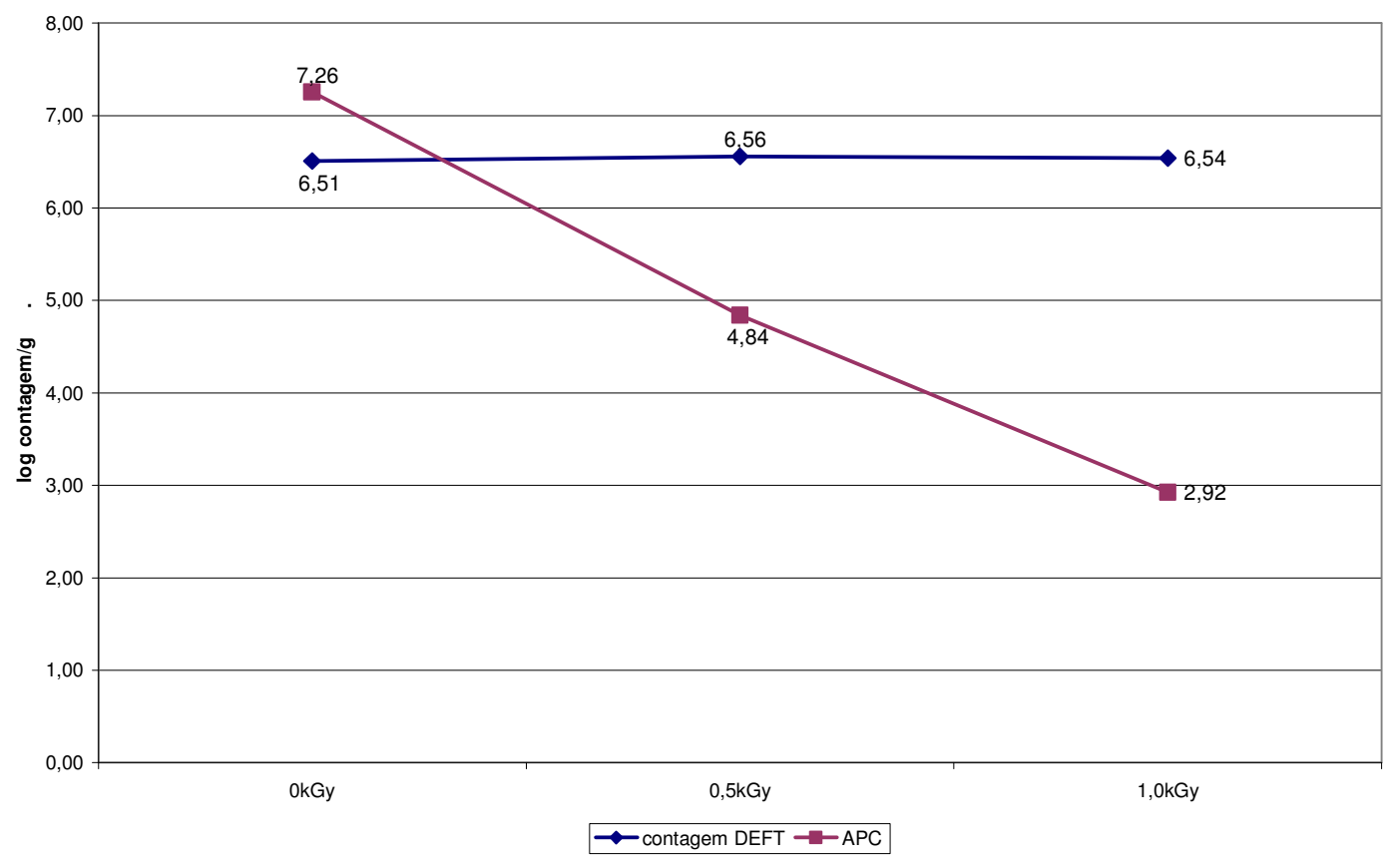

FIGURA 12 - Efeito da irradiação nas contagens DEFT e APC de repolho.

Diferentemente da maioria dos outros trabalhos que aplicaram o método microbiológico DEFT/APC na detecção do tratamento por radiação de especiarias e carne, para todas as amostras estudadas no presente trabalho (FIG. 13), o resultado do cálculo log DEFT - log APC foram bem menores que aqueles obtidos por estes autores, em geral maiores ou iguais a 3,0 log. Uma provável razão para este fato poderia ser a baixa carga microbiana original das amostras de hortaliças minimamente processadas analisadas e as baixas doses de radiação utilizadas neste trabalho (FIG. 14). 


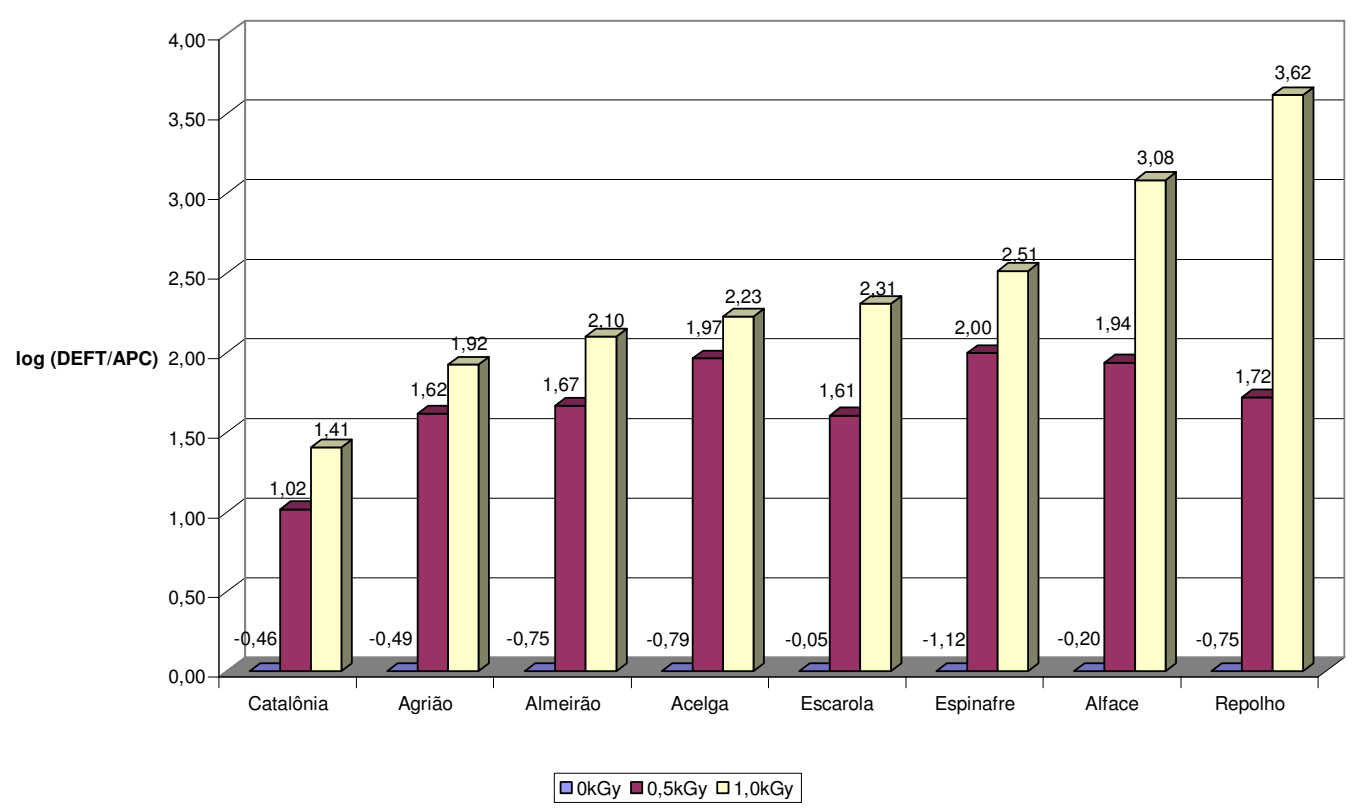

FIGURA 13 - Histograma do log (DEFT/APC) das hortaliças minimamente processadas analisadas.

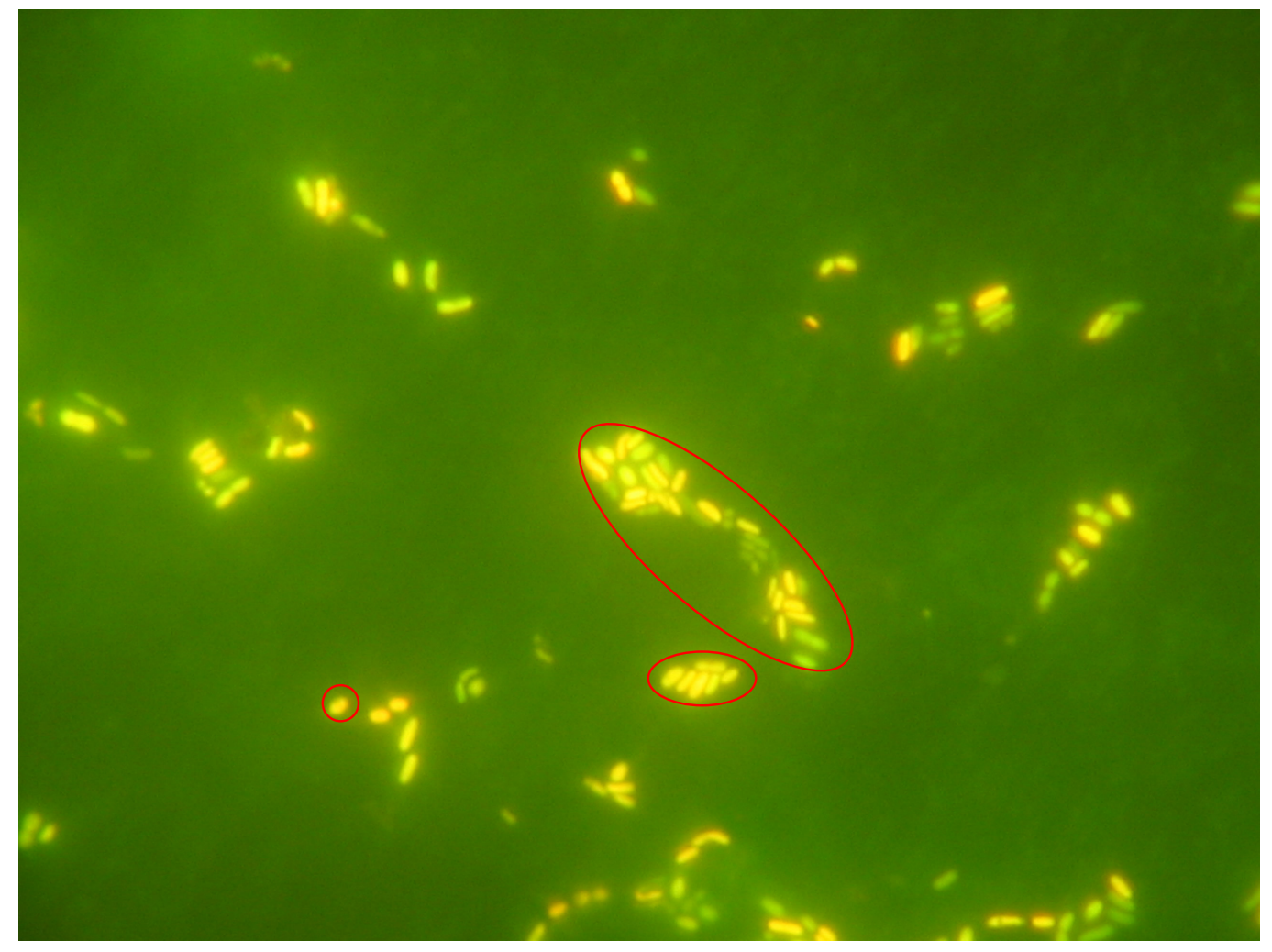

FIGURA 14 - Células bacterianas recuperadas de amostra de escarola irradiada $(0,5 \mathrm{kGy})$. Coloração: alaranjado de acridina, aumento de 1000X. 
Não foram encontrados, na literatura, dados sobre a aplicação do método microbiológico DEFT/APC na detecção do tratamento por radiação de hortaliças, o que nos remete a comparações com outros vegetais, para os quais também existem poucos dados.

A diferença log (DEFT/APC) das hortaliças minimamente processadas irradiadas com 1,0kGy neste trabalho foi superior a 2,0 log, concordando com os valores $\log$ (DEFT/APC) de 2,0 a 3,0 encontrados por Oh et al. (2002a, 2002b) para amostras de grãos de cereais e feijões irradiados com doses maiores ou iguais a $0,5 \mathrm{kGy}$.

Em estudo realizado com diferentes tipos de especiarias oriundas da Coréia e também importadas, Oh et al. (2003) propuseram que valores iguais ou superiores a 2,5 log seriam um indicativo do tratamento por radiação com uma dose de pelo menos 3,0kGy para as amostras alvo do estudo.

O presente trabalho sugere que doses iguais ou superiores a 1,0kGy, o método DEFT/APC poderia facilmente identificar uma amostra irradiada de uma amostra controle. Desta forma, poderíamos sugerir uma diferença log (DEFT/APC) superior a 2,0 unidades logarítmicas como critério para julgar se uma amostra de hortaliça minimamente processada foi irradiada com uma dose de 1,0kGy. Vale salientar que o método DEFT/APC constitui uma ferramenta útil como um teste de varredura (screening) na detecção do tratamento por radiação e que resultados positivos devem ser confirmados por metodologia padronizada. Uma vantagem adicional do método se deve ao fato de que as lâminas DEFT podem ser armazenadas por pelo menos dois meses no escuro em temperatura inferior a $6^{\circ} \mathrm{C}$, documentando desta maneira os resultados relatados. Adicionalmente, esta metodologia revela as características microbiológicas do produto no momento da análise (contagem APC) e também fornece informação sobre a história do produto (contagem DEFT). 


\subsection{Detecção do processamento por irradiação pelo teste do Cometa}

Utilizando o teste do Cometa, foi possível verificar o aumento na degradação do DNA das hortaliças estudadas, caracterizado pela presença de vários tipos de cometas, devido ao tratamento por radiação. Os diferentes tipos de cometas foram classificados visualmente de acordo com sua morfologia em quatro tipos: tipo 10 (células quase intactas com cauda curta, quando existente); tipo 20 (cauda ligeiramente maior, relativamente pouca degradação); tipo 30 (cauda comprida, com o extremo da cauda largo) e tipo 40 (cauda comprida com aparência de nuvem e núcleo com pouco material) (FIG. 15). Diferenças nítidas, em relação à frequiência de tipos de cometas entre as amostras controle e as amostras irradiadas estão apresentadas na TABELA 3.
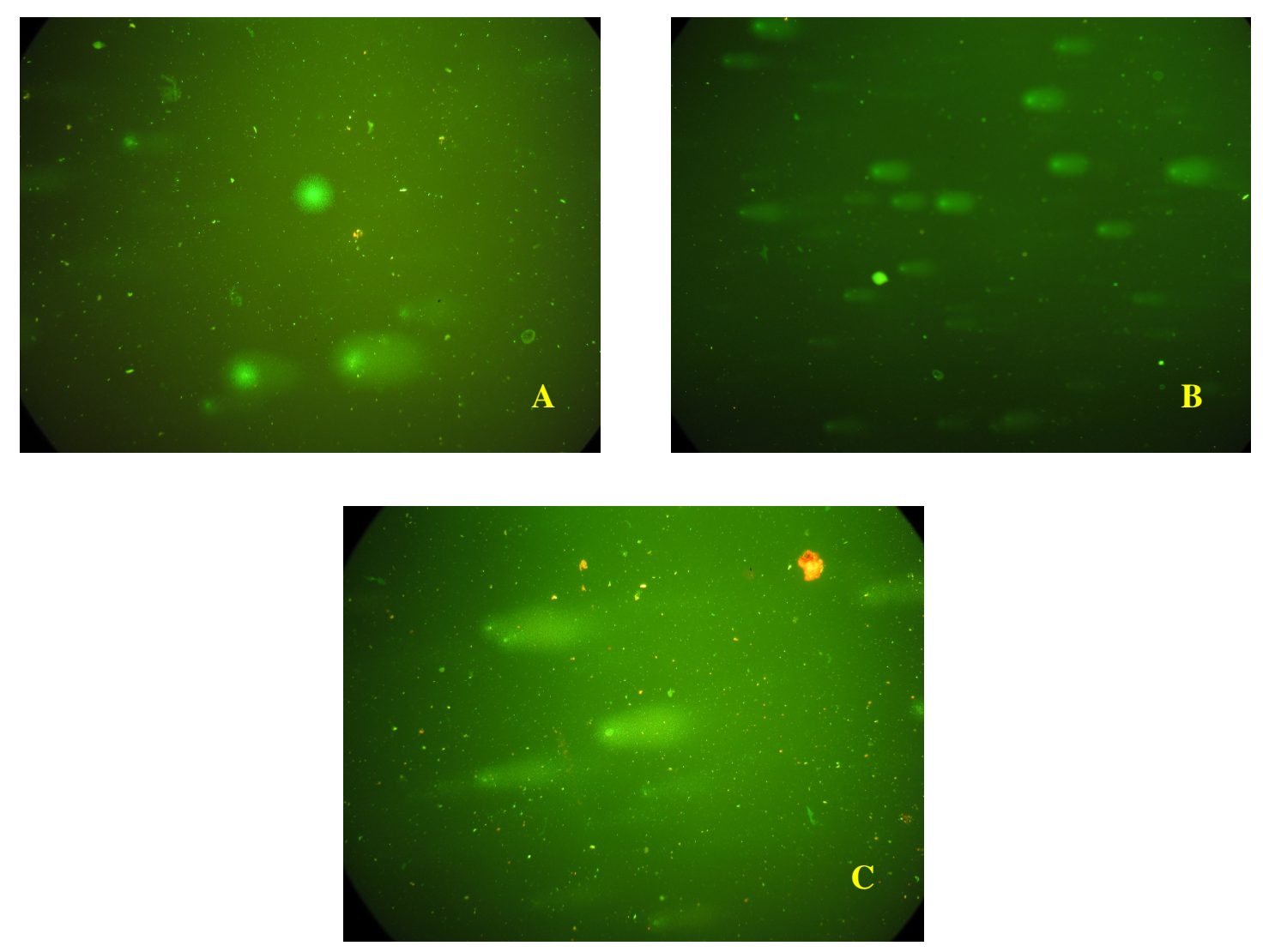

FIGURA 15 - Diferentes tipos de cometas encontrados em amostras de repolho controle (A) e irradiadas com $0,5 \mathrm{kGy}$ (B) e 1,0kGy (C). Coloração: alaranjado de acridina; aumento de 100X; anodo à direita. 
TABELA 3 - Freqüência de tipos de cometas nas amostras de hortaliças minimamente processadas estudadas após o processo de irradiação.

\begin{tabular}{|c|c|c|c|c|c|c|c|c|c|c|c|c|}
\hline \multirow{3}{*}{ Amostra } & \multicolumn{4}{|c|}{ 0kGy } & \multicolumn{4}{|c|}{$0,5 \mathrm{kGy}$} & \multicolumn{4}{|c|}{$1,0 \mathrm{kGy}$} \\
\hline & \multicolumn{12}{|c|}{ Tipos de cometa } \\
\hline & 10 & 20 & 30 & 40 & 10 & 20 & 30 & 40 & 10 & 20 & 30 & 40 \\
\hline Acelga & 41 & 49 & 10 & 0 & 0 & 18 & 82 & 0 & 0 & 0 & 82 & 18 \\
\hline Agrião & 8 & 92 & 0 & 0 & 0 & 31 & 69 & 0 & 0 & 0 & 88 & 12 \\
\hline Alface & 4 & 96 & 0 & 0 & 0 & 4 & 94 & 2 & 0 & 0 & 27 & 73 \\
\hline Almeirão & 11 & 89 & 0 & 0 & 0 & 15 & 85 & 0 & 0 & 0 & 62 & 38 \\
\hline Catalônia & 0 & 40 & 60 & 0 & 0 & 0 & 86 & 14 & 0 & 0 & 31 & 69 \\
\hline Couve & 13 & 87 & 0 & 0 & 0 & 83 & 17 & 0 & 0 & 0 & 54 & 46 \\
\hline Escarola & 86 & 14 & 0 & 0 & 4 & 96 & 0 & 0 & 0 & 14 & 86 & 0 \\
\hline Espinafre & 29 & 71 & 0 & 0 & 0 & 24 & 76 & 0 & 0 & 0 & 25 & 75 \\
\hline Repolho & 40 & 60 & 0 & 0 & 0 & 65 & 35 & 0 & 0 & 0 & 45 & 55 \\
\hline
\end{tabular}

Para a maioria das hortaliças minimamente processadas no presente trabalho, nas amostras controle foram encontrados não só cometas tipo 10, mas também freqüências crescentes de cometas tipo 20, característicos de uma degradação inicial do DNA das células. Este fato poderia ser explicado não só devido ao tempo transcorrido entre a colheita e o processamento das hortaliças, mas também ao processamento mínimo por si só. O processamento mínimo de vegetais envolve diversas etapas, como seleção, eliminação de folhas externas e partes danificadas, pré-lavagem, lavagem, sanificação com solução clorada, centrifugação, embalagem e refrigeração. Durante todos estes passos, os vegetais são submetidos a um grande estresse mecânico e químico, que podem acelerar o processo de degradação do DNA celular. De igual maneira, as próprias células do vegetal sofrem apoptose, um processo natural de degradação do DNA, que também contribuem para um aumento da freqüência de diversos tipos de cometas.

As amostras controle de couve, espinafre, repolho e acelga apresentaram pequenas quantidades de cometas tipo 10, não alcançando $50 \%$ dos cometas encontrados (FIG. 21, 23, 24, 16). Por outro lado, a amostra controle de escarola foi a única que apresentou uma elevada frequiência de cometas tipo 10, alcançando $86 \%$ do total dos cometas encontrados (FIG. 22).

Amostras de catalônia não tratadas por radiação não apresentaram cometas tipo 10, mostrando o importante processo de degradação do DNA das células vegetais destas amostras. Os cometas tipo 20 nestas amostras representaram $40 \%$ do total, seguido de $60 \%$ 
de cometas tipo 30 (FIG. 20). De maneira similar, amostras controle de alface, agrião e almeirão apresentaram baixas freqüências de cometas tipo 10, representando respectivamente $4 \%, 8 \%$ e $11 \%$. Ainda que estas amostras controle não tenham apresentado porcentagens significativas de células quase intactas, foi possível diferenciálas das amostras irradiadas (FIG. 18, 17, 19).

Quando as amostras foram submetidas ao processamento por irradiação, foi notório o incremento na degradação do DNA das células, fato este ilustrado com o aparecimento de diversos cometas tipo 20 e majoritariamente tipo 30. As amostras de alface irradiadas com $0,5 \mathrm{kGy}$ foram as que apresentaram a maior freqüência de cometas tipo 30, representando 94\% do total, seguida das amostras de catalônia, almeirão, acelga, espinafre e agrião, com 86\%, 85\%, 82\%, 76\% e 69\%, respectivamente (FIG. 16, 17, 18, $19,20,23)$.

As amostras de repolho e de escarola irradiadas com 0,5kGy apresentaram 65\% e $96 \%$ de cometas tipo 20 , respectivamente. Uma porcentagem relativamente baixa de cometas tipo 30 foi encontrada nestas amostras (FIG. 22 e 24).

O tratamento das amostras com uma dose de 1,0kGy acarretou uma pronunciada fragmentação do DNA das amostras, levando ao surgimento de cometas tipo 40 e deixando de ser encontrados cometas tipo $10 \mathrm{em}$ todas as amostras analisadas. Apenas as amostras de escarola irradiadas com 1,0kGy não apresentaram cometas tipo 40, entretanto, os cometas tipo 30 representaram $86 \%$ do total (FIG. 22).

As maiores porcentagens de cometa tipo 40 foram encontradas nas amostras de espinafre irradiadas com 1,0kGy. Nestas amostras, os cometas tipo 40 representaram $75 \%$ do total (FIG. 23). Resultados similares foram encontrados com as amostras irradiadas com 1,0kGy de alface (73\%), catalônia (69\%) e repolho (55\%) (FIG. 18, 20, 24). As demais amostras também apresentaram cometas tipo 40, embora com freqüências significativamente menores, sendo de $18 \%$ para acelga, $12 \%$ para agrião, $38 \%$ para almeirão e 46\% para couve (FIG. 16, 17, 19, 21). 


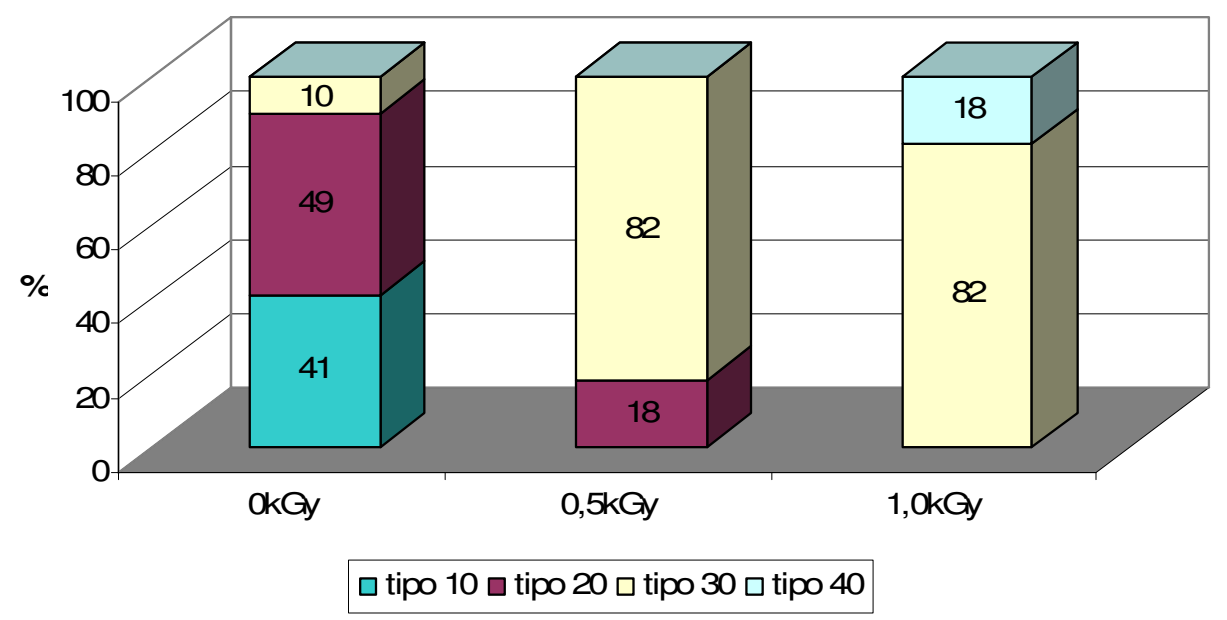

FIGURA 16 - Freqüência de tipos de cometas em amostras de acelga após o processo de irradiação.

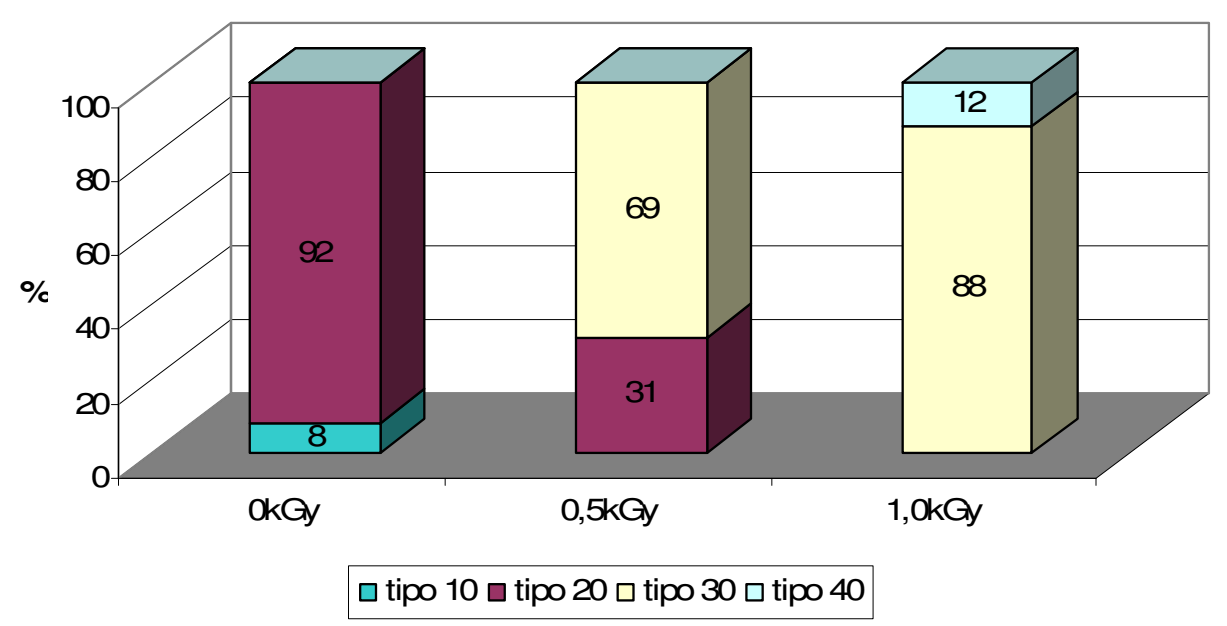

FIGURA 17 - Freqüência de tipos de cometas em amostras de agrião após o processo de irradiação.

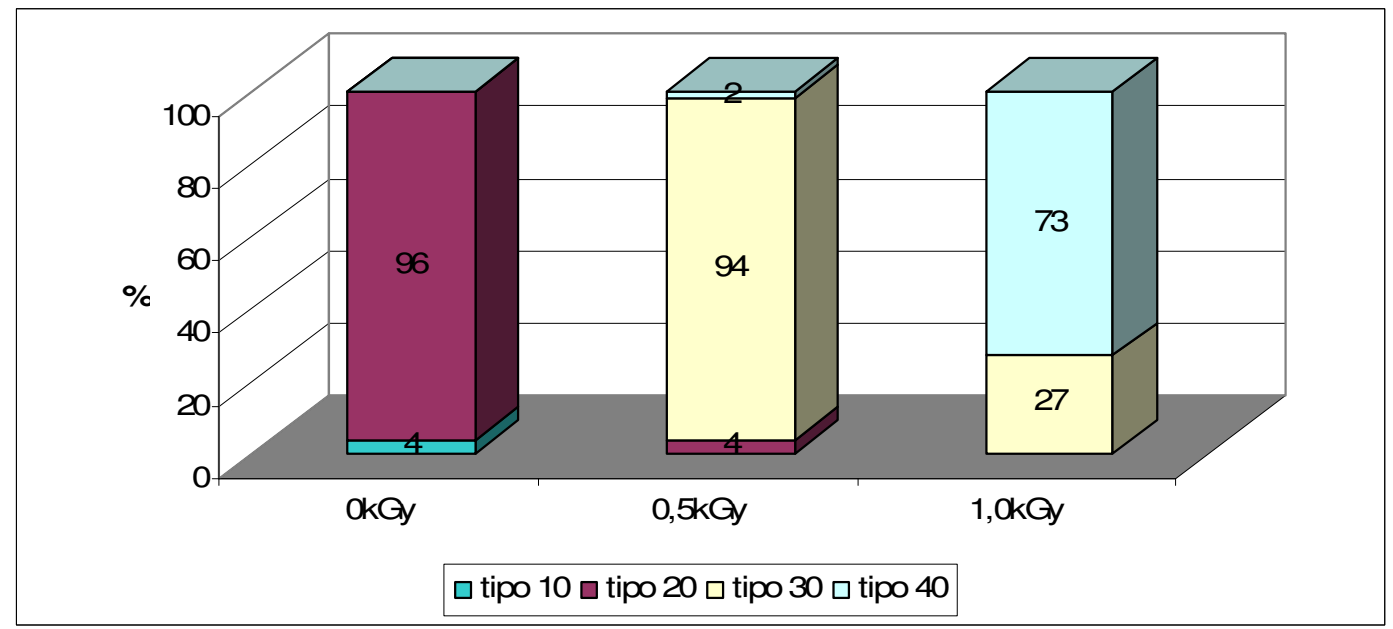

FIGURA 18 - Freqüência de tipos de cometas em amostras de alface após o processo de irradiação. 


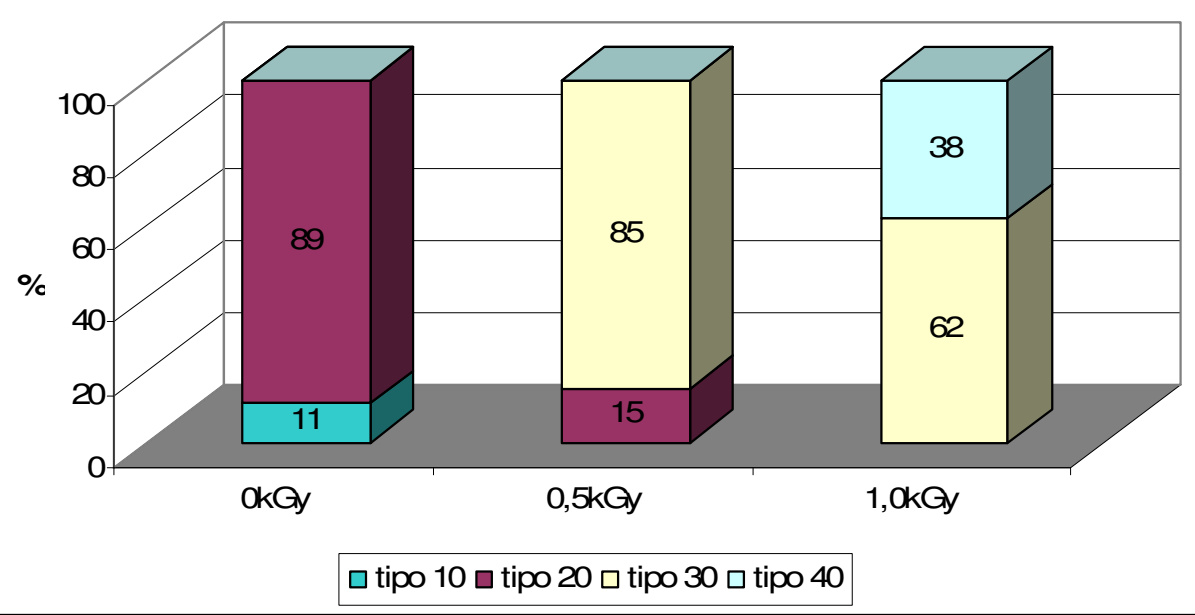

FIGURA 19 - Freqüência de tipos de cometas em amostras de almeirão após o processo de irradiação.

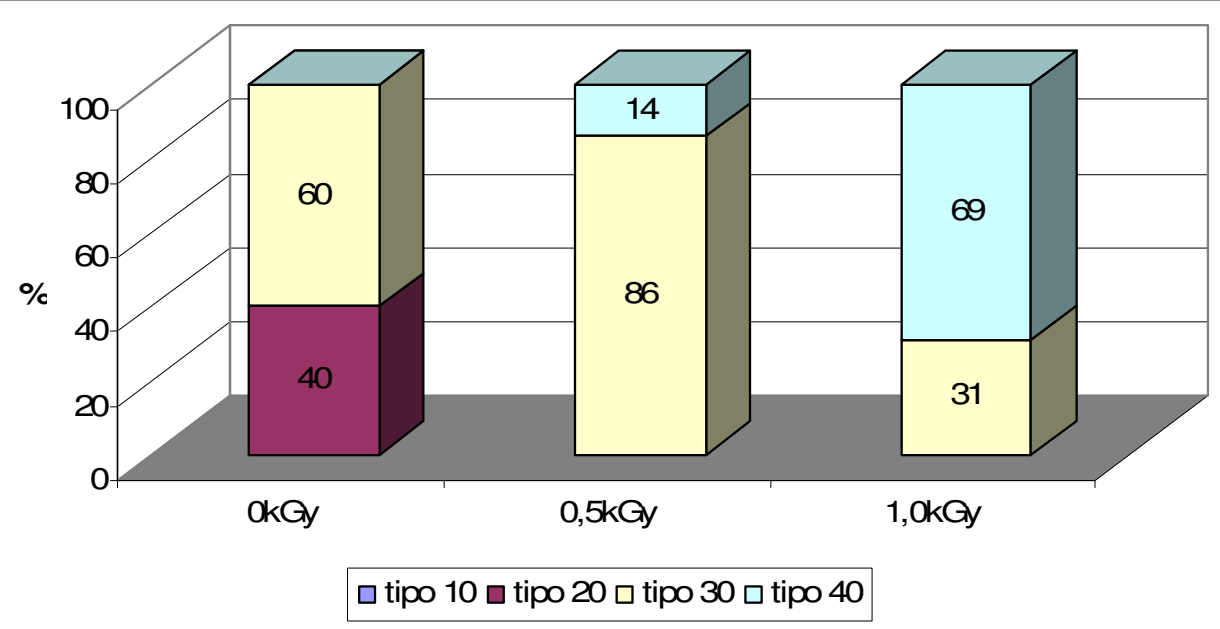

FIGURA 20 - Frequiência de tipos de cometas em amostras de catalônia após o processo de irradiação.

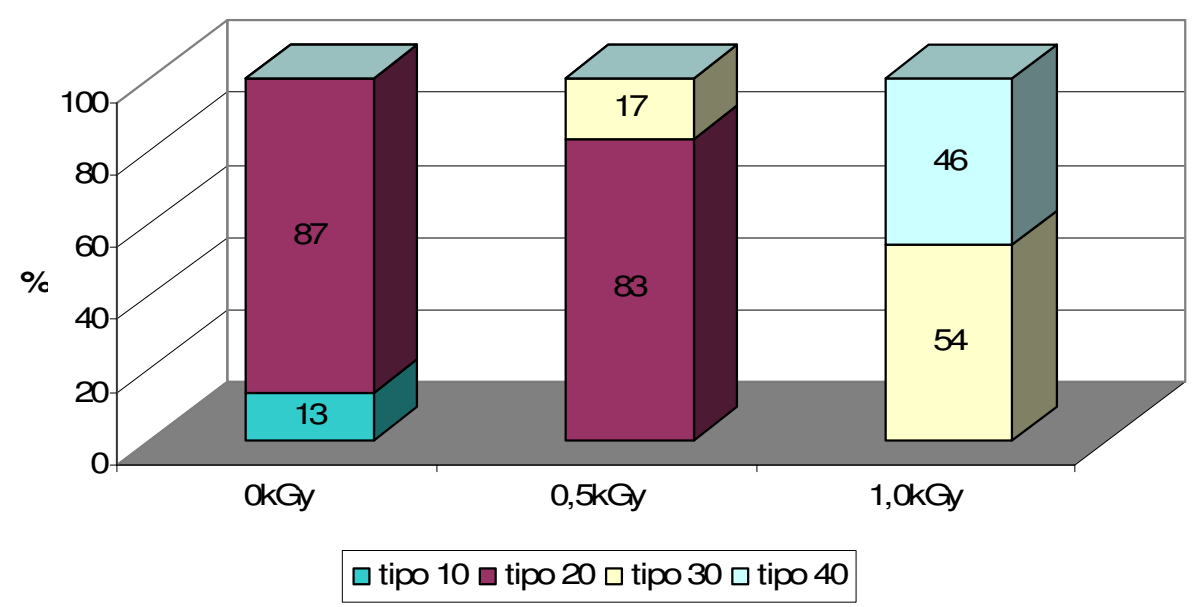

FIGURA 21 - Freqüência de tipos de cometas em amostras de couve após o processo de irradiação. 


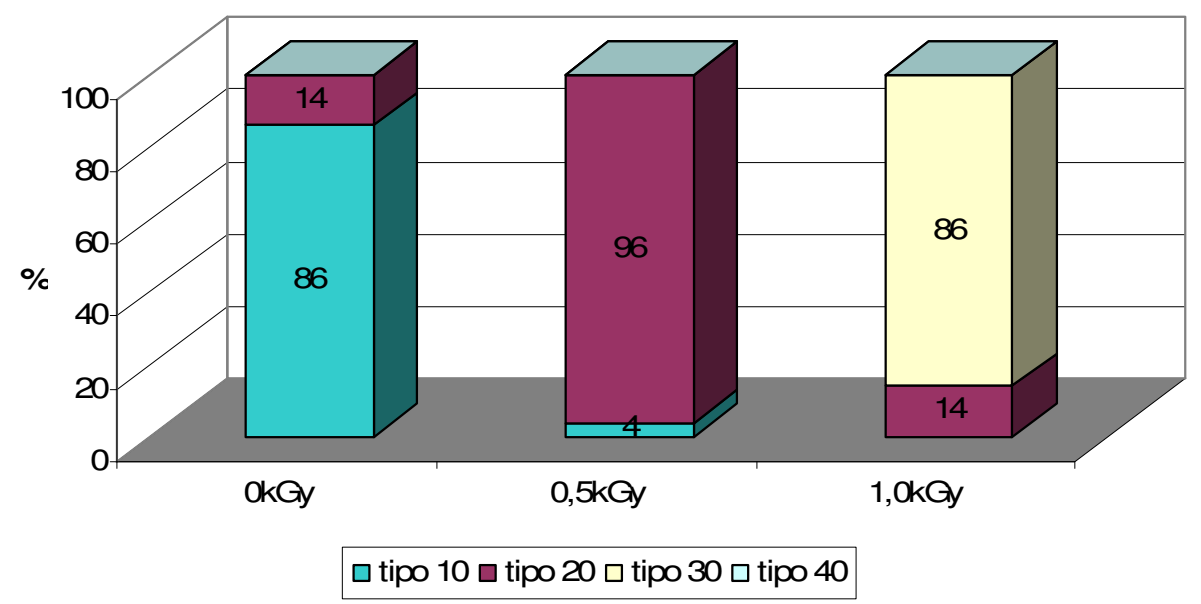

FIGURA 22 - Freqüência de tipos de cometas em amostras de escarola após o processo de irradiação.

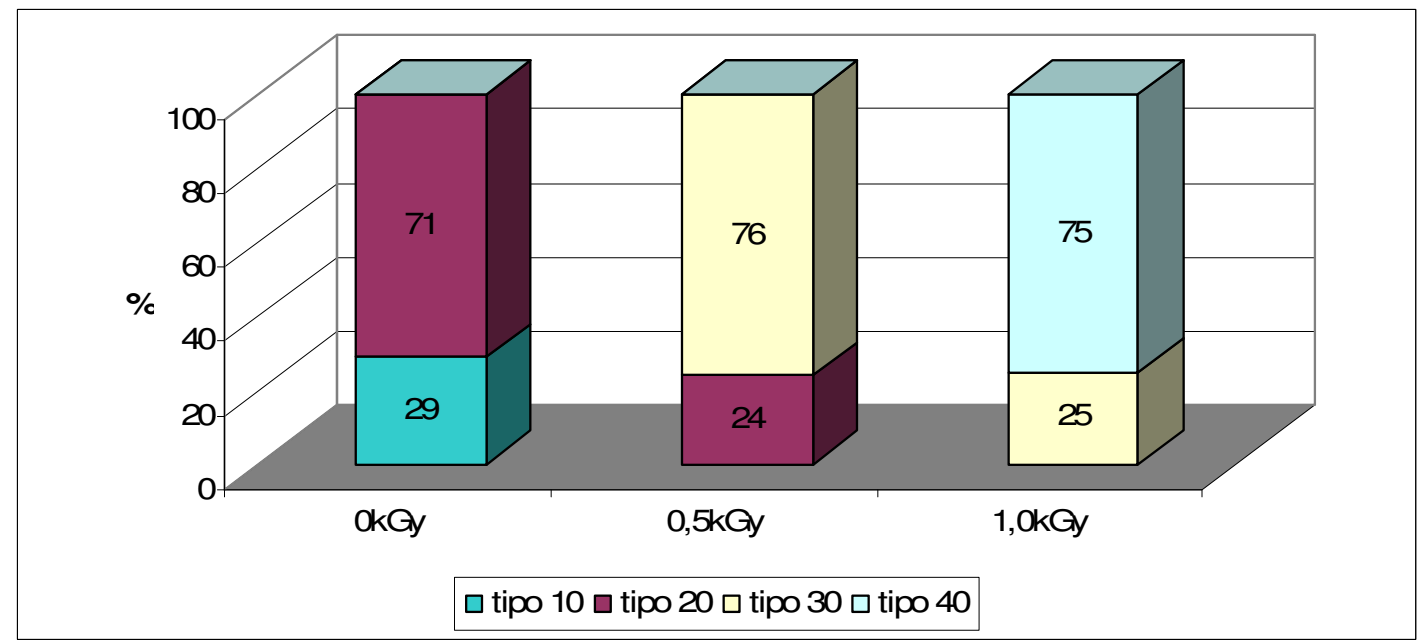

FIGURA 23 - Freqüência de tipos de cometas em amostras de espinafre após o processo de irradiação.

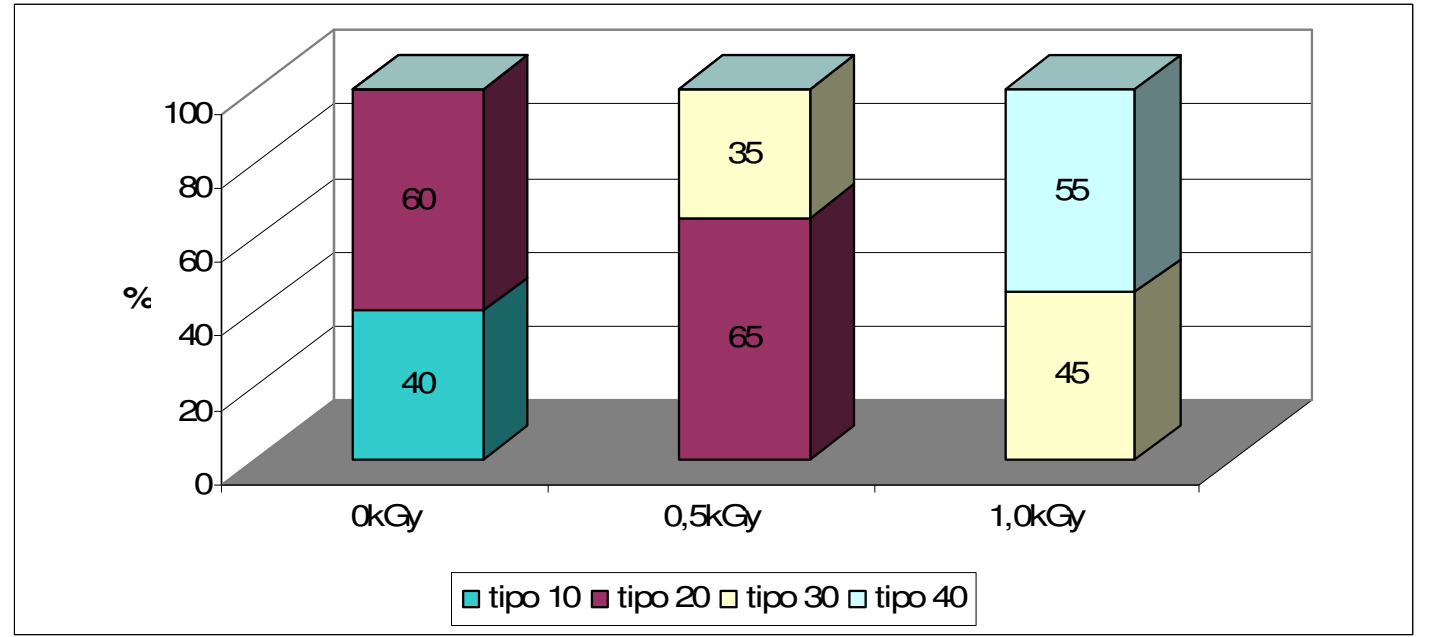

FIGURA 24 - Freqüência de tipos de cometas em amostras de repolho após o processo de irradiação. 
Um dado relevante foi o fato de que as amostras irradiadas não apresentaram células intactas, resultado este em acordo com diversos outros autores, apresentados na revisão da literatura (Araújo et al., 2004; Delincée, 1998a; Villavicencio et al., 2004, 2007; Marin-Huachaca et al., 2002; Barros et al., 2002; Khan et al., 2002). 


\section{CONCLUSÕES}

As hortaliças minimamente processadas analisadas mostraram que o processamento mínimo não garante uma boa qualidade higiênica do produto, sendo insuficiente para a redução acentuada das populações de microrganismos mesófilos e psicrotróficos.

O processamento mínimo associado a baixas doses de radiação contribuiu para aumentar a segurança microbiológica das hortaliças minimamente processadas estudadas.

$>\mathrm{O}$ método DEFT/APC pode ser usado na detecção do tratamento por radiação de hortaliças minimamente processadas, sendo uma técnica simples e eficaz de varredura do tratamento por radiação.

Para a maioria das hortaliças estudadas, um valor log $($ DEFT/APC) $>2,0$ poderia ser indicativo do tratamento por radiação com doses superiores a 1,0kGy.

O método DEFT/APC além de fornecer informação sobre o estado higiênico das amostras no momento da análise (contagem APC) e também informa sobre a história do produto (contagem DEFT).

O teste do Cometa pode ser aplicado satisfatoriamente na detecção do processamento por irradiação das amostras estudadas, constituindo uma importante técnica de varredura.

Resultados positivos obtidos pelo método microbiológico DEFT/APC e pelo teste do Cometa devem ser validados por métodos confirmatórios. 


\section{REFERÊNCIAS BIBLIOGRÁFICAS}

ALZAMORA, S. M.; LÓPEZ-MALO, A.; TAPI, M. S. Overview. In: ALZAMORA, S. M.; TAPI, M. S.; LÓPEZ-MALO, A. Minimally processed fruits and vegetables: fundamental aspects and applications. Gaithersburg: Aspen, 2000.

ANDREWS, W.H.; FLOWERS, R.S.; SILLIKER, J.; BAILEY, J.S. Salmonella. In:Compendium of Methods for the Microbiological Examination of Foods. 4.ed. Washington: APHA, 2001, p.357-380.

AHN, H. J.; KIM, J. H.; KIM, J. K.; KIM, D. H.; YOOK, H. S.; BYUN, M. W. Combined effects of irradiation and modified atmosphere packaging on minimally processed Chinese cabbage (Brassica rapa L.). Food Chem., v. 89, p. 589-597, 2005.

AQUINO, S. Efeitos da radiação gama no crescimento de Aspergillus flavus produtor de aflatoxinas e no emprego da técnica da reação em cadeia de polimerase (PCR) em amostras de grãos de milho inoculadas artificialmente. 2003. Dissertação (Mestrado) Instituto de Pesquisas Energéticas e Nucleares, São Paulo.

APHA (American Public Health Associations). Compendium of Methods for the Microbiological Examination of Foods. 4 ed. APHA: Washington, 2001.

ARAÚJO, M. M.; MARÍN-HUACHACA, N. S.; MANCINI-FILHO, J.; DELINCÉE, H.; VILLAVICENCIO, A. L. C. H. Identification of irradiated refrigerated pork with the DNA comet assay. Radiat. Phys. Chem., v. 71, p. 185-187, 2004.

BARROS, A. C.; LAMY-FREUND, M. T.; VILLAVICENCIO, A. L. C. H.; DELINCÉE, H.; ARTHUR, V. Identification of irradiated wheat by germination test, DNA comet assay and electron spin resonance. Radiat. Phys. Chem., v. 63, p. 423-426, 2002.

BELLIARDO, J.J. Methods for the detection of foodstuffs treated by irradiation. Radiat. Phys. Chem., v. 42, n. 1-3, p. 377-382, 1993.

BEUCHAT, L.R. Pathogenic microorganisms associated with fresh produce. J. Food Prot., v. 59, n. 2, p. 204-216, 1996.

BOISEN, F.; SKOVGAARD, N.; EWALDS, S.; OLSSON, G.; WIRTANEN, G. Quantitation of microorganisms on raw minced meat using the direct epifluorescenct filter technique: NMKL Collaborative Study. J. AOAC Internat., v. 75, n. 3, p. 465-473, 1992.

BRASIL. Ministério da Saúde. Decreto-Lei no 986, de 21 de outubro de 1969. Institui Normas Básicas sobre Alimentos. Publicada no DOU de 21 de outubro de 1969. Alterado pela Medida Provisória nº 2.190-34, de 23 de agosto de 2001.

BRASIL. Ministério da Saúde. Decreto n 72. 718, de 29 de agosto de 1973. Estabelece normas gerais sobre irradiação de alimentos. Publicada no Diário Oficial da União de 30 de agosto de 1973. 
BRASIL. ANVISA. Resolução RDC n 21 , de 26 de janeiro de 2001. Aprova regulamento técnico para irradiação de alimentos. Publicada no DOU de 29 de janeiro de 2001.

BRASIL. ANVISA. Resolução RDC $\mathrm{n}^{\circ}$ 12, de 02 de Janeiro de 2001. Aprova o regulamento técnico sobre padrões microbiológicos para alimentos. Publicada no DOU de 10 de janeiro de 2001.

CAC (CODEX ALIMENTARIUS COMMISSION). Codex General Standard for Irradiated foods. Codex Stand. 106-1983. Rev. 1 - 2003.

CARUSO, J. G. B.; CAMARGO, R. Microbiologia de alimentos. In: CAMARGO, R. (Ed.). Tecnologia dos produtos agropecuários-alimentos. São Paulo: Nobel, 1984, p. 3549.

CERDA, H.; HOFSTEN, B.; JOHANSON, K. J. Identification of irradiated food by microelectrophoresis of DNA from single cells. In: RECENT ADVANCES OF NEW METHODS OF DETECTION OF IRRADIATED FOOD. September, 24-26, 1991, Ancona. Proceedings of workshop. Luxembourg: Commission of the European Communities. EUR 14315, 1993, p. 401-405.

CERDA, H. Detection of irradiated fresh chicken, pork and fish using the DNA Comet Assay. Lebensm.-Wiss. u.-Technol., v. 31, p. 89-92, 1998a.

CERDA, H. Detection of irradiated frozen food with the DNA Comet Assay: Interlaboratory Test. J. Sci. Food Agric., v. 76, p. 435-442, 1998 b.

CHOUCROUN, P.; GILLET, D.; DORANGE, G.; SAWICKI, B.; DEWITTE, J. D. Comet assay and early apoptosis. Mutat. Res., v. 478, p. 89-96, 2001.

COUSIN, M.A.; JAY, J.M.; VASSADAVA, P.C. Psychrotopic microorganisms. In: DOWLES, F.P.; ITO, K. Compendium of methods for the microbiological examination of foods. 4 ed. Washington: APHA, 2001, p. 159-166.

DELINCÉE, H. Control of irradiated food: Recent developments in analytical detection methods. Radiat. Phys. Chem., v. 42, n. 1-3, p. 351-357, 1993.

DELINCÉE, H. Application of the DNA "comet assay" to detect irradiation treatment of foods. In: Detection Methods for Irradiated Foods -Current Status. England: Cambridge, UK, 1996.

DELINCÉE, H.; VILLAVICENCIO, A. L. C. H.; MANCINI-FILHO, J. Protein quality of irradiated Brazilian beans. Radiat. Phys. Chem., v. 52, n. 1-6, p. 43-48, 1998.

DELINCÉE, H. Detection of irradiated food: DNA fragmentation in grapefruits. Radiat. Phys. Chem., v. 52, n. 1-6, p. 135-139, 1998a.

DELINCÉE, H. Detection of food treated with ionizing radiation. Trends Food Sci. Technol., v. 9, n.2, p. 73 - 82, 1998 b. 
DELINCÉE, H. Analytical methods to identify irradiated food -a review. Radiat. Phys. Chem., v. 63, p. 455-458, 2002.

DIEHL, J.F. Food Irradiation: is it an alternative to chemical preservatives? Food Addit. Contam., v. 9, p. 409-416, 1992.

DIEHL, J.F. Safety of Irradiated Foods. New York: Marcel Dekker Inc., 1995.

DOYLE, M. P.; ZHAO, T.; MENG, J.; ZHAO, S. Escherichia coli O157:H7. In: DOYLE, M. P.; BEUCHAT, L. R.; MONTVILLE, T. J. Food microbiology: fundamentals and frontiers. Washington: ASM, 2001. p. 193-213.

EN 13783. Foodstuffs - Detection of irradiated food using Direct Epifluorescent Filter Technique/Aerobic Plate Count (DEFT/APC) - Screening method. Brussels: European Commitee for Standardization, 2001.

FAIRBAIRN D.W., OLIVE, P.L., O'NEIL, K.L. The comet assay: a comprehensive review. Mutat. Res., v. 339, p. 37-59, 1995.

FARKAS, J. Microbiological safety of irradiated foods. Int. J. Food Microbiol., v. 9, p. 1 $-15,1989$.

FARKAS, J.; SARAY, T.; MOHACSI-FARKAS, C.; HORTI, K.; ANDRASSY, E. Effects of low-dose gamma radiation on shelf-life and microbiological safety of precut/prepared vegetables. Adv. Food Sci., v. 19, n. 3/4, p.111-119, 1997.

FARKAS, J. Irradiation as a method for decontaminating food: a review. Int. J. Food Microbiol., v. 44, p. 189-204, 1998.

FARKAS, J. Physical Methods of Food Preservation - Preservatives and Preservation Methods. In: DOYLE, M.P, BEUCHAT, L.R, MONTVILLE, T.J., Food Microbiol.: fundamentals and frontiers. 2 ed. Washington: ASM, 2001, p. 567-591.

FARKAS, J. Irradiation for better Foods. Trends Food Sci.. Technol., v. 17, p. 148-152, 2006.

FDA - FOOD AND DRUG ADMINISTRATION. Irradiation of meat and meat products. Federal Register, v. 64, n. 36, p. 9089-9105, 1999.

FRANCO, B. D. G. M.; LANDGRAF, M. Microbiologia de alimentos. São Paulo: Atheneu, 1996.

GOULARTE, L.; MARTINS, C.G.; MORALES-AIZPURÚA, I.C.; DESTRO, M.T. ; FRANCO, B.D.G.M. ; VIZEU, D.M. ; HUTZLER, B. W.; LANDGRAF, M. Combination of minimal processing and irradiation to improve the microbiological safety of lettuce (Lactuca sativa, L.). Radiat. Phys. Chem., v. 71, p. 155-159, 2004.

HAMMERTON, K. M.; BANOS, C. Detection of irradiated spices with a microbiological method, DEFT/APC method: Detection Methods for Irradiated Foods - Current Status. Cambridge: Royal Society of Chemistry, 1996, p. 392-396. 
ICGFI - GRUPO CONSULTIVO INTERNACIONAL SOBRE IRRADIAÇÃO DE ALIMENTOS (ICGFI). Fatos sobre a irradiação de alimentos. Brasil: CDTN, 1999.

INTERNATIONAL COMMISSION ON MICROBIOLOGICAL SPECIFICATIONS FOR FOOD (ICMSF). Microorganisms in foods: microbiological specifications of food pathogens. London: Blanckie, 1996. v. 5, p. 217-264.

JAY, J. M. Modern Food Microbiology. New York: International Thomson Publishing, 2001.

JOHNSON, J. L.; ROSE, B. E.; SHARAR, A. K.; RANSOM, G. M.; LATTUADA, C. P. MCNAMARA, A. M. Methods used for detection and recovery of Escherichia coli O157:H7 associated with a food-borne disease outbreak. J. Food Prot., Des Moines, v. 58, n. 6, p. 597-603, 1995.

JONES, K.; MACPHEE, S.; TURNER, A.; STUCHEY, T.; BETTS, R. The direct epifluorescent filter technique (DEFT/aerobic plate count (APC): a screening method for the detection of irradiated food. Food Sci. Technol. Today, v. 9, n. 3, p. 141-144, 1995.

JONES, K.; MACPHEE, S.; STUCHEY, T.; BETTS, R. The direct epifluorescent filter technique (DEFT): a screening method for the detection of irradiated foods. Food Sci. Technol. Today, v. 8, n. 2, p. 105-106, 1994.

KASSIE, F.; PARZEFALL, W.; KNASMÜLLER, S. Single cell gel electrophoresis assay: a new tecnique for human biomonitoring. Mutat. Res., v. 463, p. 13-31, 2000.

KHAN, A. A.; KHAN, H. M.; DELINCÉE, H. Detection of radiation treatment of beans using DNA comet assay. Radiat. Phys. Chem., v. 63, p. 407-410, 2002.

KLAUDE, M.; ERIKSSON, S.; NYGREN, J.; AHNSTRÖM, G. The comet assay: mechanisms and technical considerations. Mutat. Res., v. 363, p. 89-96, 1996.

KOPPEN, G. Improved protocol for the plant comet test. Comet Newsletter, v. 6, p. 2-3, 1997.

KOPPEN, G.; TONCELLI, L. M.; TRIEST, L.; VERSCHAVE, L. The comet assay: a tool to study alteration of DNA integrity in developing plant leaves. Mechanisms of Ageing and Development, v. 110, p. 13-24, 1999.

KORNACKI, J.L.; JOHNSON, J.L. Enterobacteriaceae, Coliforms and E. coli as Quality and Safety Indicators. In: Compendium of Methods for the Microbiological Examination of Foods. 4. ed. Washington: APHA, 2001, p. 69-82.

LEE, N. Y.; JO, C.; SHIN, D. H.; KIM, W. G.; BYUN, M. W. Effect of $\gamma$-irradiation on pathogens inoculated into ready-to-use vegetables. Food Microbiol., v. 23, p. 649-656, 2006. 
MALYAPA, R. S.; BI, C.; AHERN, E. W.; ROTI ROTI, J. L. Detection of DNA damage by the alkaline comet assay after exposure to low-dose gamma radiation. Radiat. Res., $\mathrm{V}$. 194, p. 396-400, 1998.

MANNINEN, M.; SJÖBERG, A. M. Evaluation of a microbiological method for detection of irradiation of spices. Zeitschrift für Lebensmitteluntersuchung und -Forschung A, v. 192, p. 226-229, 1991.

MARÍN-HUACHACA， N. S.; LAMY-FREUND， M. T.; MANCINI-FILHO， J.; DELINCÉE, H.; VILLAVICENCIO, A.L.C.H. Detection of irradiated fresh fruits treated by e-beam or gamma rays. Radiat. Phys. Chem., v. 63, p. 419-422, 2002.

MARÍN-HUACHACA, N. S.; MANCINI-FILHO, J.; DELINCÉE, H.; VILLAVICENCIO, A.L.C.H. Identification of gamma-irradiated papaya, melon and watermelon. Radiat. Phys. Chem., v. 71, p. 191-194, 2004.

MARTINS, C.G.; BEHRENS, J.H.; DESTRO, M.T.; FRANCO, B.D.G.M. ; VIZEU, D.M. ; HUTZLER, B. W.; LANDGRAF, M. Gamma radiation in the reduction of Salmonella spp. inoculated on minimally processed watercress (Nasturtium officinallis). Radiat. Phys. Chem., v. 71, p. 87 - 91, 2004.

McKELVEY-MARTIN, V. J.; GREEN, M. H. L.; SCHMEZER, P.; POOL-ZOBEL, B. L.; De MEO, M. P.; COLLINS, A. The single cell gel electrophoresis assay (comet assay): A European review. Mutat. Res., v. 288, p. 47-63, 1993.

MONK, J.D.; BEUCHAT, L.R.; DOYLE, M.P. Irradiation inactivation of food-borne microrganisms. J. Food Prot., v. 58, n. 2, p.197-208, 1995.

MOREHOUSE, M. Food irradiation - US regulatory considerations. Radiat. Phys. Chem., v. 63, p. 281-284, 2002.

MORTON, R.D. Aerobic Plate Count. In: Compendium of Methods for the Microbiological Examination of Foods. 4. ed. Washington: APHA, 2001, p.63-67.

MURANO, E. A.; HAAYES, D. J.; MURANO, P. S.; OLSON, D. G.; SAPP, S. Food Irradiation - A sourcebook. USA: Ames, 1995.

NGUYEN-the, C.; CARLIN, F. The microbiology of minimally processed fresh fruits and vegetables. Crit. Rev. Food Sci. Nutr., v. 34, n. 4, p. 371 - 401, 1994.

NIEMIRA, B. A.; SOMMERS, C. H.; FAN, X. Suspending lettuce type influences recoverability and radiation sensitivity of Escherichia coli O157:H7. J. Food Prot., v. 65, p. 1388-1393, 2002.

OH, K.N.; LEE, S.Y.; YANG, J.S. Microbiological identification of beans exposed to gamma irradiation (DEFT/APC method). Food Sci. Biotech., v. 11, n. 3, p. 257-259, 2002a.

OH, K.N.; LEE, S.Y.; YANG, J.S. Detection of gamma-irradiated grains by using DEFT/APC method. Korean Food Sci. Technol., v. 34, n. 3, p. 380-384, 2002 b. 
OH, K.N.; LEE, S.Y.; LEE, H.J.; KIM, K.E.; YANG, J.S. Screening of gamma irradiated spices in Korea by using a microbiological method (DEFT/APC). Food Control, v. 14, p. 489-494, 2003.

OLIVE, P. L. DNA damage and repair in individual cells: applications of the comet assay in radiobiology. Int. J. Radiat. Biol., v. 75, n. 4, p. 395-405, 1999.

ÖSTLING, O.; JOHANSON, K. J. Microelectrophoretic study of radiation-induced DNA damages in individual mammalian cells. Biochem. Biophys. Res. Commun., v. 123, p. 291-298, 1984.

PETTIPHER, G.L. The Direct Epifluorescence Filter Technique. Letchworth (UK): Research Studies Press, 1983.

PETTIPHER, G. L.; MANSELL, R.; MCKINNON, C. H.; COUSINS, C. M. Rapid membrane filtration epifluorescent microscopy technique for direct enumeration of bacteria in raw milk. Appl. Environ. Microbiol., v. 39, p. 423-429, 1980.

RADOMYSKI, T.; MURANO, E.A.; OLSON, D.G; MURANO, P.S. Elimination of pathogens of significance in food by low-dose irradiation: a review. J. Food Prot., v. 57, n. 1, p. 73-86, 1994.

RADOMYSKI, T.; THAYER, D. W. Reduction of Salmonella spp. and strains of Escherichia coli O157:H7 by gamma radiation of inoculated sprouts. J. Food Prot., v. 63, p. 871-875, 2000.

ROJAS, E.; LOPEZ, M. C.; VALVERDE, M. Single cell gel electrophoresis assay: methodology and applications. J. Chromatogr. B, v. 722, p. 225-254, 1999.

ROSS, G. M.; McMILLAN, T. J.; WILCOX, P.; COLLINS, A. R. The single cell microgel electrophoresis assay (comet assay): technical aspects and applications. Mutat. Res., v. 337, p. 57-60, 1995.

SCHREIBER, G.A.; HELLE, N.; BÖGL, K.W. Detection of Irradiated Food - methods and Routine Applications. Int. J. Radiat. Bio., v. 63, n. 1, p. 105-130, 1993.

SOMMERS, C.H.; BOYD, G. Variations in the radiation sensitivity of foodborne pathogens associated with complex ready-to-eat food products. Radiat. Phys. Chem., v. 75, p. 773-778, 2006.

SOUZA, L. H. L. A manipulação inadequada dos alimentos: fator de contaminação. Higiene Alimentar, v. 20, n. 146, p. 32-39, 2006.

SZABO, E.A.; SCURRAH, K.J.; BURROWS, J.M. Survey for psychrotrophic bacterial pathogens in minimally processed lettuce. Lett. Appl. Microbiol., v. 30, n. 6, p. 456-460, 2000 .

THAYER, D. W.; RAJKOWSKI, K. T. Development in irradiation of fresh fruits and vegetables. Food Technol., v. 53, n. 11, p. 62 - 65, 1999. 
TORBEN, L.; HANSEN, H.B.; BOISEN, F. Comparison of three methods for detection of herbal food supplement irradiation. Eur. Food Res. Technol., v. 223, p. 39-43, 2006.

TRITSCH, G.L. Food irradiation. Rev. Nut., v. 16, n. 7/8, p. 698-701, 2000.

VILLAVICENCIO, A. L. C. H. Avaliação dos efeitos da radiação ionizante de 60 Co em propriedades físicas, químicas e nutricionais dos feijões Phaseolus vulgaris L. e Vigna unguiculata (L.) Walp. 1998. Tese (Doutorado) - FCF/USP, São Paulo.

VILLAVICENCIO, A.L.C.H.; MANCINI-FILHO, J.; DELINCEÉ, H.; BOGNAR, A. Effect of irradiation on anti-nutrients (total phenolics, tannins and phytate) in brazilian beans. Radiat. Phys. Chem., v. 57, n. 3-6, p. 289-293, 2000.

VILLAVICENCIO, A.L.C.H.; ARAÚJO, M. M.; BALDASSO, J. G.; AQUINO, S.; KONIETZNY, U.; GREINER, R. Irradiation influence on the detection of geneticmodified soybeans. Radiat. Phys. Chem., v. 71, p. 491-494, 2004.

VILLAVICENCIO, A.L.C.H.; ARAÚJO, M. M.; MARÍN-HUACHACA, N. S.; MANCINI-FILHO, J.; DELINCÉE, H. Identification of refrigerated poultry with the DNA comet assay. Radiat. Phys. Chem., v. 71, p. 189-191, 2004.

VILLAVICENCIO, A.L.C.H.; FANARO, G. B.; ARAÚJO, M. M.; AQUINO, S.; SILVA, P. V.; MANCINI-FILHO, J. Detection of Phakopsora pachyrhizi by polymerase chain reaction (PCR) and use of germination test and DNA comet assay after e-beam processing in soybean. Radiat. Phys. Chem., v. 76, p. 1878-1881, 2007.

WIRTANEN, G.; SJÖBERG, A.M.; BOISEN, F.; ALNKO, T. Microbiological screening method for indication or irradiation of spices and herbs: A BCR collaborative study. $\boldsymbol{J}$. AOAC Intern., v. 76, n. 3, p. 674-681, 1993.

WIRTANEN, G.; SALO, S.; KARWOSKI, M.; SJÖBERG, A. M. A microbiological screening method for the indication of irradiation of frozen poultry meat. Zeitschrift für Lebensmitteluntersuchung und-Forschung A, v. 200, p. 194-197, 1995.

WHO. Safety and nutritional adequacy of irradiated food. Genebra, 1994. 